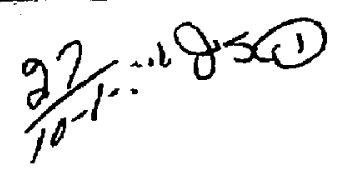

$$
D R-0426 x
$$
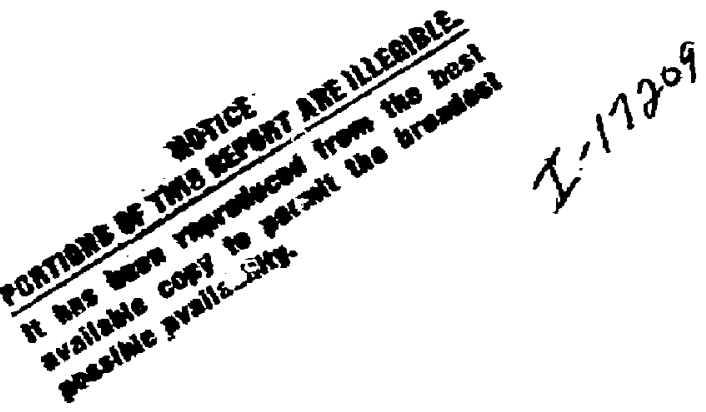

UCID-20174

\title{
Electrochenical Determinaticn \\ of the Corrosion Behavior of Candidate Alloys \\ Proposed for Containment \\ of High Level Nuclear Waste in Tuff
}

Robert S. Glass

George E. Overturf

Robent E. Garrison

R. Daniel McCright

\section{June 1984}

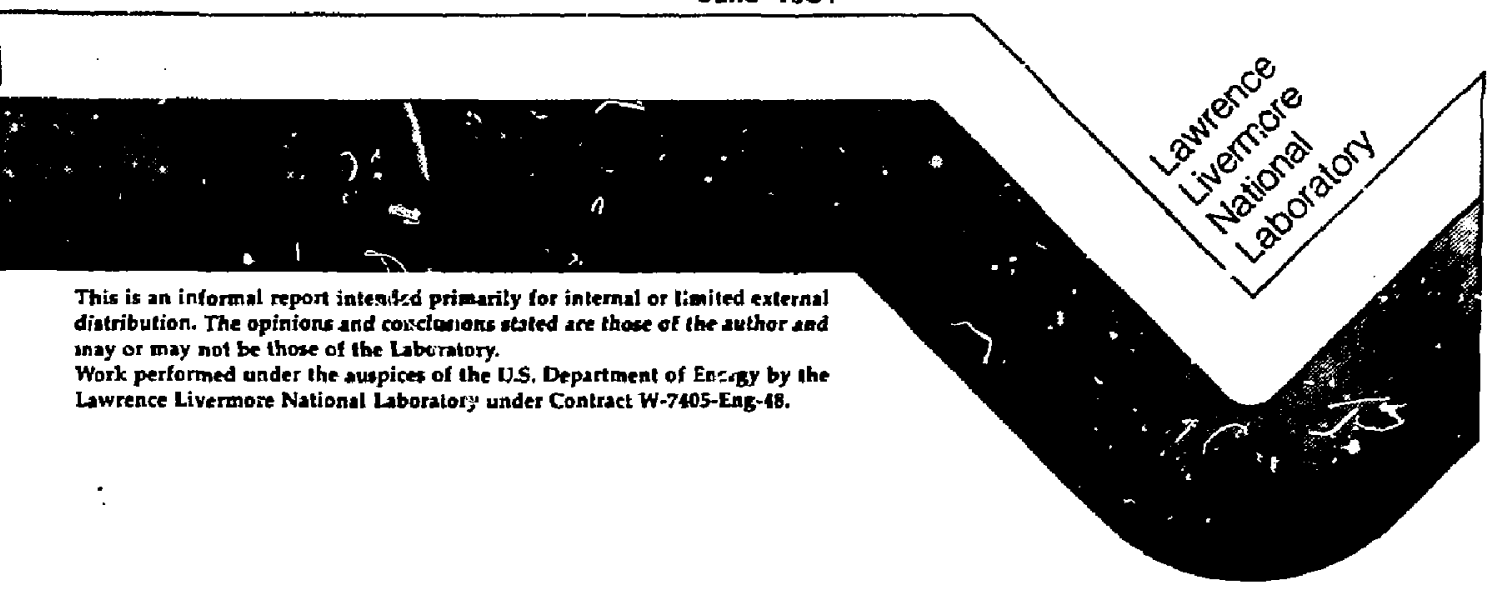

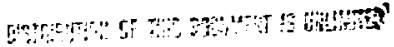


Electrochi mical Determinacjon of the Corrosion Behavior of Candidate A!loys Proposed for Containment of High Level Nuclear Waste in Tuff

Robert S. Glass, George E. Overturf, Robert E. Garrison, and R. Daniel McCright

UCID--20174

June 18, 1924

2305001768

ABSTRACT

Long-term geological disposal of nuclear waste requires corrosionresistant - inister materials for encapsulation. Several austenitic stainless steels are under consideration for such purposes for the disposal of high-level waste at the candidate repository site located at Yucca Mountain, Nevada. With regard to corrosion considerations, a worst case scenario at this prospective repository lacation would result from the intrusion of vadose water. This preliminary study focuses on the electrochemical and corrosion behavior of the candidate canister materials under worst-case repository environments. Electrochemical paraneters related :o localized attack (e.g., pitting potentials) and the electracherrical corrosion rates nave been examined.

\section{Introduction}

Lawrence Livermore National Laboratory (LLNL) is responsible for high-level nuclear waste package development for the Nevada Nuclear Waste Storage Investigations project as a part of the Department of Energy's Civilian Radioactive Waste Management (CRWM) Program. The waste package

\section{DISCLAIMER}

This rtport was prepured as an eccoust of work sponsored by an agency of the United States Gc.vernment. Neither the United Stutes Government aor any agency thereof, nor any of their employees, makes any warranty, express or implied, or assumes enj lezal tiability or responsibility for the accuracy, completeness, or uxefulness of any information, apperatus, product, of process disclowed, or represents that its use would aot infrisge privately ownod rifhts. Reference herein to any specific commertinl product, process, or service by trade aame, trademark. manufacturer, or otherwixe doea not necestarily constitute or imply its endotientent, recommendation, or fsvoring by the United States Government or any agency thereor. The views and opinions of authors expresuod berein do not necessarily state or rellect those of the United States Goverawent or any agency theteor. 
effort at LLNL is developing multi-barriered packages for safe, permanent disposal in a repositary in the unsaturated zone at Yucca Mountain. The corrosion-resistant austenitic stajnless steels AISI $304 \mathrm{~L}, 316 \mathrm{~L}, 321$, and 347 and the high-nickel alloy 825 are under investigation for use os canister materials in the encapsulation of nuclear waste materials (1). The canister must have sufficient corrosion resistance to survive for 300-1000 years in the repository environment. Repository environmental considerations include the potentially aggressive situation where vadose water intrudes into the repository and contacts the emplaced stainless steel canisters. The repository horizon would be located in welded tuff above the static water table at Yucca Mountain. Sorre water could percolate down through fractures in the rock and enter the horizon of the repository. The environment surrounding the waste canisters for much of the containment period is therefore expected to be air and water vapor (steam). A potentially worst-case environment vould be partial to complete inundatjon with vadose water when the radioactive waste has decayed appreciably and the canisters have cooled to below $95^{\circ} \mathrm{C}$ surface temperature (the boiling point of water at the repository elevation).

As a result of their widespread structural use, the electrochemical and general corrosion properties of stainless steels have been extensively investigated (2-6). Localized forms of corrosion such as pitting and crevice corrosion, although again extensively investigated, require additional work to resolve outstanding issues. Different environments impose various constraints on the selection of the appropriate austenicic stainless steel for the desired application.

The purpose of this prel "minary study was to survey the electrochemical parameters relating tó general corrosion (e.g., corrosion potential, corrosion current) and to localized corrosion (e.g., pitting potential, protection 
potential). These parameters were examined for the candidate steels in water characteristic of the prospective repository sitt. The data reported here represent the results to oate and it is to be stressed that much work remains to de done. A more detailed analysis of the significance of the electrochemical results presented here is underway. The mechanisms of localized attack as well as the ro?e of thermal oxide films in corrosion resistance needs to be better understood for the prospective environmental conditions. In addition, the effect of ionfzing radiation on the chemical environment surrounding the waste canisters needs to be evaluated in 1 ight of possible changes in corrosion reststance.

\section{Experimental Considerations}

The water used in this experimental work was obtained from the $J-13$ well at the Nevarfa Iest Site. While water samples have not yet been obtained from the location of the prospective repository in Yucca Mountain, near-by well J-13 produces water which has flowed through Topopah Spring member where it lies at lower elevation and is in the saturated zone. The water from the $\mathfrak{J}-13$ well is taken as a reference water in the repository horizon. The chemjcal composition of tuff-conditioned $\mathrm{J}-13$ water is given in Table 1 .

The small amounts of the anions such as $\mathrm{Cl}^{-}$suggest a relatively benign environment with regard to the expected performance of the candidate stainless steel. When additions of $\mathrm{Cl}^{-}$were intentionally made to solution, analytical grade $\mathrm{NaCl}$ was used. The metal samples used were obtained from Metal Samples, Inc. and were used in the mill-annealed condition.

The electrochemical cell used consisted of a one 1 flask with inlets for the working, counter, and reference electrodes. The reference electrode used was in all cases a saturated calomel electrode (S.C.E.). All potentials quoted 
in the paper were correcter to reference an S.C.E. at $25^{\circ} \mathrm{C}$. Graphite rods were used as the counter electrodes. Unless otherwise stated, the solutions were air-saturated and static. When deaeration was used, ultra-high purity argon was used to bubble the solution throughout the experiment.

The working electrodes employed usually consisted of discs $1 \mathrm{~cm}^{2}$ in area which were masked off by neoprene o-rings in a ccmercjal gasket electrode holder (Princeton Applied Research). In some cases, a $5 \mathrm{~cm}^{2}$ cylinder of the Material of interest was used. Generally, the electrodes were oretreated by polishing to 400 grit SiC and rinsing with DI water. The ASTM specifications for elemental ranges for the alloys used in this work are given in Table 2. The actial analyses for the alloys used are listed in Table 3. Unless otherwise stated, the anodic polarization curves were obtained potentiodynamically at a $1 \mathrm{mV} / \mathrm{s}$ scan rate. The electrochemical parameters $E_{\text {corr }}, E_{p i t}$ and $E_{\text {prot }}$ were determined at this scan rate. The electrochemical corrosion rates obtained by Tafel extrapolation and Tinear polarization resistance (L.P.R.) were also obtained at this scan rate. Electrochemical data was generally obtained with the aid of a EG\&G Princeton Applied Research Model 350A Corrosion Measurement Console. In some cases, the polarization curves were obtained using an EG\& Princeton Applied Research Model 173 potentiostat in combination with a model 175 function generator and $176 \mathrm{i} / \mathrm{E}$ converter.

Description of Electrochemical Tr nniques

The tachniques used in the present study to extract electrochemical parameters include cyclic anodic polarization, Tafel extrapolation and linear polarization resistance (LPR). Excellent descriptions of these techniques are given in the literature $(2-4, \vec{i}, 8)$, and only a brief recounting is given here. 
Cyclic anodic polarization curves are obtained by anodically scanning the sample (working electrode) to enforced potentials anodic to the corrosion potential ( $E_{\text {corr }}$ ), then reversing the direction of the scan back to more negative valves. Current flowing through the working electrode/counter electrode couple is continuously inonitored during the scan. Such a scan, whose potential waveform is triangular, yields electrochemical values of interest such as the pitting potentia) ( $\left.E_{p i t}\right)$ and the protection potential

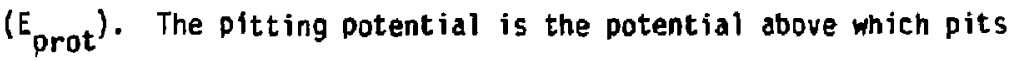
spontaneously initiate and grow. The protection potential is the potential below which previously initiated pits repassivate and no new pits form. At potentials between the pitting and protection potential, new pits are not initiated, but any previously initiated pits continue to grow. The values of the pitting and protection potential relative to the corrosion potential are indicative of the pitting susceptibility of the tested alloy in the tested environment. It is to be noted that the values for $E_{p i t}, E_{p r o t}$ and $E_{\text {corr }}$ are in many cases dependent upon the particular electrochenical technique employed. In this study, the potentiodynamic method was used in which the potential is contincially scanned anodicaliy with time. For consistency, the technique was used throughout this screening study for all the alloys. Other techniques, such as potentiostatic methods, are currently being used to investigate in more detail the values of $E_{p i t}$, $E_{\text {prot }}$, etc. An "electrochemical" corrosion ate can be deternined either by Tafel extrapolation or LPR. In LPR, a linear polarization measurement is performed in the potential range close to, and on either side of the corrosion potential (e.g., $\pm 10 \mathrm{mv})$. In this region, the current-potential relationship can be linearized anu from plots of $i-E$ one can determine a " polarization resistance." With the additional knowledge of some fundamental 
electrochemical parameters (Tafel coefficients), a corresponding

electrochenical corrosion rate (in $\mu A / \mathrm{Cm}^{2}$ ) can be calculated. This is

then easily converted into a corrosion rate in mils-per-year through use of Faraday's Law. The interested reader is directed to the references above for a detailed description of the theory behind this technique.

Tafel extrapolations can also be used to calculate corrosion rates. In this method, one linearly scans the potential region to a few hundred millivolts anodic and cathodic of the corrosion potential. Plots are then made of the potential (or potential relative to the corrosion potential, e.g., overpotential) vs the logarithm of the current. By extrapolation of the linear segments of either arodic or cathodic branches back to the measured corrosion potential, the corrosion current can be obtained. Again, the corrosion current $c$ ar, be easily converted into a corrosion penetration rate. The interested reader is again directed to the literature references given above for a detailed description of the theory of this technique Results and Discussion General Electrochemistry

Most of the electrochemical work to date has been performed in the relatively benign $\mathrm{J}-13$ well water, and in enviranments somewhat more aggressive than this. The addition of chloride ion will make the environment more aggressive towards austenitic stainless steels (2-4), and chloride ion has been purposely added in somp experiments.

A typical anodic polarization curve is shown in Fig. 1. The curve shown here is for $304 \mathrm{~L}$ in $\mathrm{J}-13$ well water at $90^{\circ} \mathrm{C}$. This curve displays features common to all polarization curves obtained in the $\mathrm{J}-13$ well water environment. 'In this figure, the electrochemical paramet, 's $E_{\text {corr }}$, $E_{p i t}$, $E_{p r o t}$, and the passive current region are identified. Scanning anodically 
from $E_{\text {corr }}$, $304 L$ remains passive unt $j l$ the pitting potential is reached. This characteristic potential, which is influenced largely by such parameters as temperature and chloride ion concentration, is marked by a large increase (several orders of magnitude) in the anodic current density. The exact potentials are influenced by the surface pretreatment and the particular electrochemical metnod employed $(2,9)$. The closer $E_{p i t}$ is to $E_{\text {corr }}$, the greater susceptibility lo pitting may result from increase in the oxidizing potential of the media, whicn would shift $\mathbf{E}_{\text {corr }}$ to more positive values.

From plots like those in fig. 1, tabulations of electrochemical parameters for some of the prospective canister materials nave been made. Figure 2 lists values of $E_{\text {corr, }}, E_{p i t}, E_{\text {prot, }}$ and $E_{p i t}-E_{p r o t}$ for $304 L$ in $\mathrm{J}-13$ well water at various temperatures. The parameter $E_{p i t}-E_{p r o t}$ has been used previousiy to "rank" alloys in terms of crevice corrosion resistance (10). In the above study, the value of $E_{p i t}-E_{p r o t}$ determined in aerated $3.5 \% \mathrm{NaCl}$ at $25^{\circ} \mathrm{C}$ correlated very well with the natural crevice corrosion weight loss in seawater after several years imersion for the austenitic stainless steels investigated. As the value of $E_{p i t}-E_{p r o t}$ becomes larger, the resistance to crevice corrosion decreases. Also, greater difficulty in repassivating growing pits is indicated by larger values of $E_{p i t}-E_{p r o t}$. The data snown for $304 \mathrm{~L}$ in Fig. 2 indicate no clear temperature dependence for $E_{\text {corr }}$ in the range of 60 to $90^{\circ} \mathrm{C}$. That $\mathrm{J}-13$ well water is relatively benign inay account for this. In harsher environments, one generally expects a more dramatic shift of $E_{\text {corr }}$ to more negative potentials with increasing temperature which in most cases indicates a loss of passive oxide film stability, e.g., film thinning. For $E_{\text {pit }}$ values, again, no significant temperature dependence is observed. A shift in E negative potentıals can, in some cases, be an indication of greater 
susceptibility to pitting corrosion, and is commonly observed as the temperature is increased $(2-4)$. For the case at hand, the values of $E_{p i t}$ are sufficiently removed from $E_{\text {corr }}$ such that pitting will not occur. The vilue of $E_{p i t}-E_{\text {prot }}$ generally shows a tendency to adopt larger values with increasing temperature in agreenent with the negative temperature dependence of $E_{\text {prot. }}$. This could indicate a siightly greater susceptibility to crevice attack. Further experiments to confirin this will need to be performed. At $60^{\circ} \mathrm{C}$ and $70^{\circ} \mathrm{C}$, the $E_{\text {prot }}$ values are essentially equivalent to the $E_{p i t}$ values. This indicates that pits can be repassivated at the same potential at which they initiate.

Electrochemical parameters for 316L and 1-825 equivalent to those for $304 \mathrm{~L}$ in $\mathrm{J}-13$ well water are presented in Figures 3 and 4, respectively. Again, there is no strong dependence of the corrosion potential on temperature in this environment, at least in the temperature range of $50-90^{\circ} \mathrm{C}$. The values for $E_{\text {corr }}$ for $316 L$ and I-825 are fairly close, and generally more positive than those for 304L. The observation of more noble corrosion potentials for the more nighly alloyed materials may be related to the well-acknowledged roles of Mo and $N_{i}$ as passivating agents. These alloying constituents may shift the corrosion potential positive by creating more stable passive films or by decreasing the overvoltage for the cathodic half-reaction in the overall corrosion process.

A stronger negative temperature dependence of $E_{p i t}$ values for $316 \mathrm{~L}$ and I-825 was observed than for 304L. The values of $E_{p i t}$ for $316 \mathrm{~L}$ are generally more positive than those for $304 \mathrm{~L}$ which indicates a lower susceptibility to pitting in this environment. This again may be related to the well-known role of the alloying consistent Mo in increasing the pitting resistance in stainless steels (2-4). The alloy I-825, on the other hand, shows values of 
$E_{p i t}$ lower than those for $304 \mathrm{~L}$ at $80^{\circ}$ and $90^{\circ} \mathrm{C}$. In any case, for all of the alloys, 304L, 3]6L, and I-825, the pittini: potential is significantly removed (positive) from $E_{\text {corr }}$ such that in the absence of a large change in solution chemistry to more oxidizing conditiuns, no spontaneous pitting of any of these alloys in this environment is likely to occur.

No statisticaliy significant trends $i: 1 E_{\text {prot }}$ or in $E_{p i t}-f_{\text {prat }}$ are noted for either 316L or 1-825. For all of the alloys 304L, 316L, and I-825, the small values of $E_{p i t}-E_{p r o t}$ indicate that it is relatively easy to electrochemically repassivate growing pits.

In-situ corrosion testing is performed by sandwiching flat metal specimens between ribbed Teflon washers. All of the alloys examined in this work (304L, 316L, 321, 347, and I-825) showed some "preferential attack" in the crevices under the Jeflon washers. At the one year time period, however, in $\mathrm{J}-\mathrm{i} 3$ well water at temperatures ranging between $50^{\circ}$ and $100^{\circ} \mathrm{C}$, the attack was very minor. Many samples showed what would be better described as a "stain" rather than having any real significant depth of penetration (15).

It is to be noted that while the electrochemical parameters of $E_{p i t}$, $E_{p r o t}$ and cther general i-E relationships were determined through the potentiodynamic technique, more sophisticated electrochemicai techniques exist $(2,9,11)$. The values reported in this work should, therefore, be considered as preliminary in thi sf, e that they were evaluated as part of a ceneral screening study. More powerful and more time consuming electrochemical techniques exist for the examination of localized corrosion such as the pit-propagation rate method used in evaluating pitting phenomena (9).

Surface preparation also plays a role in determining potential measurements, both the precision and reliability, particularly for $E_{\text {corr }}$. An in-depth study evaluating this factor for ausienitic steels is now underwa 
Chloride ion acts as a very aggressive anion with regard to localized corrosion (pitting and crevice attack) of stainless steels (2-4). It is possible, due to evaporation and radiolysis effacts, that $\mathrm{J}-13$ well water may "concentrate" in an actual repository environment. To evaluate the effect of increased $\mathrm{Cl}^{-}$levels, this anion was purposely added to $\mathrm{J}-13$ well water. Further experiments are currently underiyay using "concentrated" $\mathrm{J}-13$ (by boil-down) to evaluate effects on candidate alloy electrochemistry and will be reported in a future report.

Prelininary data for a solution ten times more concentrated than $\mathrm{d}-13$ indicate no significant effect on the electrochemical corrosion behavior of 316L. (with respect to J-13). Apparently the increase in beneficial effects associated with ions such as $\mathrm{NO}_{3}^{-}$and $\mathrm{HCO}_{3}^{-}$off set effects due to jncrease in $\mathrm{Cl}^{-}$concentration. The beseficial effects of certain anions on mitigating the detrimental effects of chloride has been jiscussed by Smialowska (12). The electrochemical effects on $316 \mathrm{~L}$ in deaerated $\mathrm{J}-13$ well water at $90^{\circ} \mathrm{C}$ containing an additional $100 \mathrm{ppm}$ and $1000 \mathrm{ppm} \mathrm{Cl}^{-}$are shown in the anodic polarization curves in Figs. 5 and 6 , respectively. In Fig. 5 , $E_{\text {corr }}$ was $-0.190 \mathrm{~V}$. Upon scanning to more positive potentials from this point, a passive region exists unti one gets to approximately $0.27 \mathrm{~V}$ at which point the current begins to increase rapidly with potential. This point can be equated with the pitting potential. On the other hand, in Fig. 6 with 1000 ppm $\mathrm{Cl}^{-}$, there is no clear breakaway point in the current-potential curve and pits may oegin to nucleate at potentiais very close to the corrosion potential, which is at $-0.23 \mathrm{~V}$. However, significant pitting will not occur until potentials more positive than appruximately $0.08 \mathrm{~V}$ are reached.

The effect of increased $\mathrm{Cl}^{-}$concentration is apparent in the increased susceptibility to pitting which manifests itself by the proximity of Epit to $E_{\text {corr }}$ and in the magnitudes of the current densities. 
Figure 7 displays the relationstip between the electrochemical parameters $E_{\text {corr }}$ and $E_{p i c}$ for $304 \mathrm{~L}$ in $3-13$ well water at $90^{\circ} \mathrm{C}$ with varying concentrations of $\mathrm{NaCl}$. The general trend for both of these values is to become more negative with ircreasing chloride ion concentration. It is also observed that as the concentration of chloride (i.e., $\mathrm{NaCl}$ ) is increased she values of $E_{\text {pit }}$ approach more closely the values of $E_{\text {corr }}$. This indicates a greater susceptibility to pjeting as small changes in solution oxidation potential can shift 304L into the pitting regime (e.9., compare Figs. 5 and 6). Sharp drops in $E_{p i t}$ are noted in going from 25 to $50 \mathrm{ppm} \mathrm{MaCl}$ and from 50 to $1000 \mathrm{ppm} \mathrm{NaCl}$. At the other extremes $(0$ to 25 and 10.0 to $30,000 \mathrm{ppm}$ NaC1) less abrupt changes are noted.

The electrochemical parameters of interast for 304L in J-13 well water with $75 \mathrm{ppm}$ and $1000 \mathrm{ppm} \mathrm{NaCl}$ added as a function of temperature are shown in Figs. 8 and 9, respectively. For the case of $75 \mathrm{ppm} \mathrm{NaCl}$, a negative imperature dependence of $E_{\text {corr }}$ and $E_{p i t}$ is noted, as expected. In the temperature ranje investigated, $E_{p i t}$ is far removed from $E_{\text {corr }}$ such that pitting shoule not be a problem in this environment.

For the case of $\mathrm{J}-13$ well water containing $1000 \mathrm{ppm} \mathrm{NaCl}$ shown in Fig. 9 , severc. points are made. First, it is noted that there exists no strong temperature dependence of either $E_{\text {corr }}$ or $E_{p r o t}$ in this environment. The values for $E_{\text {corr }}$ are more negative than those in the case of $75 \mathrm{ppm} \mathrm{NaCl,}$ which is as expected given the harsher conditions. The value of $E_{\text {corr }}$ at $60^{\circ}$ is curious and deserves re-examination. $E_{p i t}$ values, also in accordance with the harsher enviroisient, are much more negative than those of the $75 \mathrm{ppm}$ $\mathrm{NaCl} \mathrm{Case}$, and show a negative temperature dependence. The proximity of $E_{\text {corr }}$ and $E_{\text {pit }}$ values indicate a nigher susceptibility to pitting than was the case for $75 \mathrm{ppm} \mathrm{NaCl}$. The values for $E_{p i t}-E_{p r o t}$ show no temperature 
dependence. This implies that the electrochemical repassivation of growing pits is temperature-insensitive in this environment.

\section{Corrosion Rates}

Tafel extrapolation and linear polarization resistance have been used to determine the corrosion rates of candidate steels under a variety of

conditions. The rates deternined by these methods are to be ccmpared to those obtained by weight-loss measurements which were measured following 3548 and $5000 \mathrm{hr}$ exposure periods in $\mathrm{J}-13$ well water. The weight-loss data is given in Table 4. The data for three replicate samples has been averaged in the calculation of corrosiun rates.

Typical plots for Tafel extrapolation and LPR for $316 \mathrm{~L}$ in $\mathrm{J}-13$ well water at $80^{\circ} \mathrm{C}$ are shown in Figs. 10 and 11 , respectively. The plots were obtained and electrochemical corrosion rates determined with the aid of a PAR Mooei 350 Corrosion Measurement Console which is autonatically controlled by an internal computer interface. The system automatically calculates a corrosion rate in terms of mils-per-year (mpy) from the measured corrosion current $\left(1_{\text {corr }}\right)$. The s.rstem also calculates anodic and cathodic Tafel coefficients (ATC and CTC, respectively) which are used in the LPR measurement to calculate a corrosion current. The corrosion current is measured directly in the Tafel extrapolation technique, and is determined by the intersection of the extrapolated linear anodic and cathodic Tafel lines.

Figure 12 shows corrosion rates determined by Tafel extrapolation and LPR for 304L in J-i3 well water containing an additional $1000 \mathrm{ppm} \mathrm{NaCl}$ at various temperatures. A similar correlation between the two different types of electrochemical measurements is given in Fig. 13 which displays data for $304 \mathrm{~L}$ in $\mathrm{J}-13$ well water at $90^{\circ} \mathrm{C}$ containing different concentrations of $\mathrm{MaCl}$. 
Considering the difference in the electrochemical techniques, and the low corrosion rates measured, reasonably good agreement is obtained (well within an order of magnitude) for most of the alloys in most environments. One can see in Fig. 13 that there is a significant increase in corrosion rate in going from 75 to $1000 \mathrm{ppm} \mathrm{NaCl}$ and from 1000 to 30,000 ppm $\mathrm{NaCl}$ as might be expected given the jump in severity of the environment. In this figure, the LPR data appear to be more internally consistent as one would expect a large jump in the corrosion rate in going from 1000 to $30,000 \mathrm{ppm} \mathrm{NaCl}$. The data obtained by Iafel extrapolation for $30,000 \mathrm{ppm} \mathrm{NaCl}$ is anomalous and is being re-examined.

The electrochemically measured corrosion rates (by Tafel extrapolation) for prospective canister materials in tuff-conditioned $\mathrm{J}-13$ well water as a function of temperature are given in Fig. 14. The general trend for 304L, I-825 and 321 is to sinow an increased corrosion rate with temperature, as expected for austenitic stainless steels (2-4). However, the changes in corrasion rate with teinperature are slight and one would be tempted to interpret the corrosion rate for all the alloys in $\mathrm{J}-13$ to be generally effectively independent of temperature (in the temperature range surveyed), especially for $316 \mathrm{~L}, 317 \mathrm{~L}$, and 347 . As a resuit of the relativeìy benign environment of $3-13$ well water, this would not be a surprising result for the temperature range considered and the 1 imitations of the measurement technique employed. One might consider the electrochenically measured rates to be a conservative upper bound. The relatively large corrosion rate for $316 \mathrm{~L}$ at $70^{\circ} \mathrm{C}$ (although it is still low, 1 mpy $=1$ inch in 1000 years) is anomalous and deserves reexamination.

The fact that the electrochemical measurements represent a conservative upper bound for corrosion rates is exemplified by comparison with the measured 
corrosion rates obtained by weight-loss shown in Table 3 . These rates are all very much lower than the electrochemically measured rates. This again is the result of the diffjculty of measuring absolute corrosion rates in the relatively benign enyironnent at hand by either weight-loss or electrochemical methods, and in the large differences in the methods used to determine the rates. Differences in initial surface preparation and cleaning procedures, as well as the fact that "fresh" surfaces were used in the electrochemica? experiments aiso may account for some of the discrepancies. Normally, as a rule of thumb in corrosion measurements, if the corrosion rates were several mils-per-year, one would expect an order-of-magnitude agreenent betweer the two techniques. As a result of such low corrosion rates in this system, reasonable agreement (although certainly not within an order of magnitude) is believed to be obtained here.

Following exposure to $\mathrm{J}-13$ well water for various times, the candidate alloys were removed and the corrosion rates were determined electrochemically. The results of such a study following exposure for 100 , 500, 1000, and 2500 hours at $90^{\circ} \mathrm{C}$ are shown in Fig. 15. Ther $\geq$ is no clear correlation of corrosion rate with time as determined by Tafel extrapolation for any of the alloys. This same result is found in the weight-loss data. Again, the benignity of the environment may account for this and the comments given above apply here also. By comparison with the $90^{\circ} \mathrm{C}$ data in Fig. 14 , which was obtained using "fresh" unexposed samples, it is observed that following exposure to $3-13$ well water the corrosion rates are observed to decrease at all :imes for all alloys. This may be the result of the formation of a nore protective passive film on the surface following exposure. It is also observed that the measured corrosion rates in Fig. 15 more nearly match those of weight-loss measurements given in Table 3 (in many cases an 
"order-of-magnitude" agreenent is obtained, especially when comparison is made between the 5000 hours weigit-loss data and the longer of the exposure times for the electrochemical samples. This may be due to more sinilar conditions of the alloy surface for the two measureinent techniques following exposure than was the case for the comparison with "fresh" samples given in Fig. 14. The values for $304 \mathrm{~L}$ and 321 at 2500 hours in Fig. 15 are anomalous and will be reexamined.

Role of Oxide Films

The canisters are expected to experience a high-teriperature air environment for a significant time period after emplacement. Temperatures of approximately 200 to $250^{\circ} \mathrm{C}$ at the canister surface for up to 50 years may be reached for spent fuel waste packages (1). In addition, during the in-can glass solidification process proposed for comercial and defense high-level wastes, canister surface temperatures as high as $580^{\circ} \mathrm{C}$ may be reached during the processing. Previous studies (13) have indicated that for 304L, a maximum sensitivity to pitting will occur following oxidation in ory air at $300^{\circ} \mathrm{C}$. This pitting susceptibility results from a change in the semiconducting properties of the oxide film.

We have recently initiated studies to examine the role of thermally formed oxide films on stainless steeis on the resultant pitting susceptibility in chloride media. Preliminary results suggest that oxide films formed on $304 \mathrm{~L}$ in dry air at $650^{\circ} \mathrm{C}$ for 1 hour inhibit overall pitting in $1000 \mathrm{ppm} \mathrm{Cl}^{-}$ media at $90^{\circ} \mathrm{C}$. That is, the overall current density achieved upon anodic polarization is lower at any given potential for the oxidized specimen relative to an unoxidized specimen. However, this is a measure of the overall pitting current density and does not account for the possibility that some pits may grow more rapidiy than others. Therefore, the maximum pit depth for 
the oxidized specimen may be equal to or exceed that for the unoxidized specimen. Further examination is in progress.

Once pitting has been initiated on the thermally oxidized specimen by scanning to positive potentials, if the scan is reversed to more negative potentials tl.e resultant current densities are similar to those obtained on the unoxidized specimens. This means that the films are not self-healing and if penetration of aggressive $\mathrm{Cl}^{-}$ion into the film is allowed, the beneficial effects of the film are permanently destroyed. Further work will be more fully documented in a later report.

\section{Future Work}

Among the topics which are currently under investigation, or planned for the near future are the following:

1. Examination is underway to determine the sensitivity of evaluated parameters, e.g., $E_{\text {corr }}, E_{p i t}$, etc., to surface preparation and test procedures. In this regard, data reproducibility is being critiqued.

2. More sophisticated electrochemical techniques are being used to investigate the nechanisms of pit inteintion. ta analytical techniques (e.g., Auger electron spectroscopy) are being used to investigate the role of alloying constituents in pit initiation and repassivation.

3. Hechanisms of crevice corrosion for candidate alloys are being investigated. This lacalized form of attack has not yet been well 
explored for this program and may provide differentiation of candidate alloys with regard to suitability as canister materials.

4. Effects of radiolysis on the electrochemical corrosinn proporties of prospective canister materials are being evaluated. Both in-situ gamma field and ex-situ modeling experiments are planned for the near future.

5. The electrochemical corrosion behavior of 310 stainless steel oontaining low carbon (to avoid sensitization) and high nitrogen (for greater strength and increased localized corrosion resistance) is under investigation. This material has been proposed for use in piping in nuclear power plants (BUR) and may be a viable canister material.

\section{Conclusions}

1. $\mathrm{J}-13$ well water is a relatively benign environment towards the candidate alloys $304 \mathrm{~L}, 316 \mathrm{~L}, 31 \mathrm{~h}, 321,347$, and I-825.

Electrochemical results, obtained from anodic polarization curves, indicate that sponianeous pitting of these materials should not occur for these alioys at temperatures up to $100^{\circ} \mathrm{C}$ in this environment.

2. The values of $E_{\text {corr }}$ in $J-13$ well water for many of the prospective materials is relatively insensitive to temperature up to $90^{\circ} \mathrm{C}$. $E_{p i t}$ values become slightly more negative with temperature. Values for $E_{p i t}-E_{\text {prot }}$ show no systenlatic temperature depentence. 
3. Concentration of $\mathrm{J}-13$ well water to ten times the original concentrations of solute species does not appear to significantly Iffect the fundamental electrochemical corrosion behavior of $316 \mathrm{~L}$.

4. However, increase of the $\mathrm{Cl}^{-}$ion concentration alone in $\mathrm{J}-13$ well water, creates a more aggressive solution towards austenitic stainiess steels which is indicated in the electrochemical corrosion test results. With increase in $\mathrm{Cl}^{-}$concentration in $\mathrm{J}-13, \mathrm{E}_{\text {corr }}$ and $E_{p i t}$ values get more negative and the alloy becomes more susceptible to pitting. This is in agreement with orevious work on the effect of $\mathrm{Cl}^{-}$.

5. The electrochemical techniques of Tafel extrapolation and inear polarization resistance to determine corrosion rates yield no clear dependence on temperature in $\mathrm{J}-13$. That the corrosion rates are so low in this environment may account for the observed lack of temperature dependence. This result is obtained by both weight-loss and electrochemical measurements. When $\mathrm{NaCl}$ is purposely added to $\mathrm{J}-13$, the electrochemically measured corrosion rates increase, particularly when more than $75 \mathrm{ppm} \mathrm{NaCl}$ is added.

6. When compared to corrosion rates measured by weight-loss in-situ, the electrochemically measured rates are always larger. This is particularly true when "fresh" unexposed surfaces are used in the electrochemical experiments. When the electrochemical samples are immersed in solution under the same conditions as the weight-7oss samples, thereby generating similar surfaces (oxide films) the correlation is better (in some cases within an order of magnitude). The electrochemically measured rates should be taken as conservative upper bounds. 
7. On the basis of weight-loss measurements and electrochemical experiments in $\mathrm{j}-13$ we 11 water at temperatures up to $100^{\circ} \mathrm{C}$ it is not possible to definitively distinguish the behavior of $304 \mathrm{~L}, 316 \mathrm{~L}$, $317 \mathrm{~L}, 321,347$, or I-825 as to which is a more suitable canister material. Alt of these candidate materials exhibit sufficiently low corrosion rates and no indication of spontaneous pitting. Present experimental results indicate that a canister fabricated from any one of these candidate alloys could meet the 300-1000 year containment objective. However, due to the possible long-term low-temperature sensitization of 304L (14), 316L or one of the stabilized grades of steel may be preferable canister materials. Crevice corrosion is a form of attack to which many stainless alloys show some degree of susceptiblity and the performance of the candidate alloys may provide a means of differentiating between them in J-13 well water. Future work will be directed toward more sophisticated testing to differentiate the crevice corrosion susceptibility of the candidate alloys.

\section{Acknowledgments}

The assistance of William F. Frey in performing some of the laboratory experiments is gratefully acknowledged. 


\section{REFERENCES}

1. R. D. MCCright, H. Heiss, if. C. Juhas, and R. H. Logan, UCRL-89988, Nov., 1983.

2. A. J. Sedricks, Corrosion of Stainless Steels, John Wiley and Sons, New York (1979).

3. H. H. Uhlig, Corrosion and Corrosion Control, Second Edition, John Wiley and Sons, Inc., New York (1971).

4. M. G. Fontana and r. D. Greene, Corrosion Engineering, McGraw-Hi11, New York (1978).

5. L. L. Shreir, Corrosion, Vols, 1 and 2, Newnes-Butterworths, Boston (1979).

6. R. W. Staehle, B. F. Brown, J. Kruger, and A. Agrawal, eds., Localized Corroston, part III, pp. 311-447, National Association of Corrosion Engineers, Houston (1974).

7. A. J. Bard and L. R. Faulkner, Electrochemical Methads, John Hiley and Sons, Inc., New York (1980).

8. J. O'M. Bockris and A.K.N. Reddy, Modern Electrochemistry, Vols. 1 and 2, Plenum Press, New York (1970).

9. B. C. Syrett, Corrosion, 33, 221 (1977).

10. B. E. Wilde in Localized Corrosion, on cit., p. 342.

11. S. Smialowska and M. Czachor in Localized Corrosion, op cit., p. 353.

12. S. Szkiarska-Smialowska, ibid, pp. 312-34i.

13. G. Bianchi, A. Cerguetti, F. Mazza, and S. Torchio in Localized Corrosion, op cit., p. 399.

14. M. J. Fox, "An Overview of Low-Temperature Sensitization," LLNL Contractors report UCRL-15619, Dec. 1983.

15. R. D. HcCright, "General and Lacilized Corrosion Resistance of Austenitic Stainless Steels in $\mathrm{J}-13$ Water," Lawrence Livermore National Laboratory Report (in preparation). 
TRBLE 1 Analysis of $\mathrm{J}-13$ Water

(average of 6 samples, by OES-ICP and IC)

\section{pem}

A1

As

B

$\mathrm{Be}$

CJ

Co

Cu

$\mathrm{Fe}$

Li

Mn

Ho

$\mathrm{Ni}$

P

$\mathrm{Pb}$

Se

Si

Sr

U

V

Zn

$\mathrm{Ca}$

$k^{+}$

$\mathrm{Mg}$

$\mathrm{Na}$

$\mathrm{Cl}$

$F$

$\mathrm{NO}_{3}^{-}$

$\mathrm{SO}_{4}$

$\mathrm{HCO}_{3}^{-}$
$<0.020$

$<0.060$

$0.11 \pm 0.01$

0.003

$<0.003$

$<0.003$

$<0.003$

$<0.004$

$0.044 \pm 0.001$

$<0.0005$

$0.013 \pm 0.002$

$<0.008$

$<0.124$

$0.022 \pm 0.003$

$<0.100$

$27.0 \pm 0.1$

$0.054 \pm 0.005$

$<0.084$

$0.011 \pm 0.001$

$<0.008$

$13.0 \pm 0.1$

$5.5 \pm 0.3$

$1.92 \pm 0.01$

$43.4 \pm 0.3$

$7.1+0.3$

$2.4 \pm 0.1$

$9.1 \pm 0.2$

$18.5 \pm 0.1$

$132 \pm 6$ 
TABLE 2 Alloy Composition for Reference and Alternative Canister and Overpack Materials

\begin{tabular}{|c|c|c|c|c|c|c|c|c|c|}
\hline \multirow[b]{2}{*}{$\begin{array}{l}\text { Common Alloy } \\
\text { Designations }\end{array}$} & \multirow[b]{2}{*}{$\begin{array}{c}\text { UNS* } \\
\text { Designations }\end{array}$} & \multicolumn{8}{|c|}{ Chemical Composition (weight per cent) } \\
\hline & & $\begin{array}{l}\text { Carbon } \\
\text { (max.) }\end{array}$ & $\begin{array}{c}\text { Manganese } \\
(\max .)\end{array}$ & $\begin{array}{l}\text { Phosphorus } \\
(\max .)\end{array}$ & $\begin{array}{l}\text { Sulfur } \\
\text { (max.) }\end{array}$ & $\begin{array}{r}\text { Silicon } \\
(\max .)\end{array}$ & $\begin{array}{c}\text { Chromium } \\
\text { (range) }\end{array}$ & $\begin{array}{l}\text { Nicke } 1 \\
\text { (range) }\end{array}$ & $\begin{array}{l}\text { Other } \\
\text { Elements }\end{array}$ \\
\hline $304 \mathrm{~L}$ & 530403 & 0.030 & 2.00 & 0.045 & 0.030 & 1.00 & $18.00-20.00$ & $8.00-12.00$ & $N=0.10 \max$ \\
\hline $316 \mathrm{~L}$ & 531603 & $0: 030$ & 2.00 & 0.045 & 0.030 & 1.00 & $16.00-18.00$ & $10.00-14.00$ & $\begin{array}{l}\text { Mo: } 2.00-3.00 \\
N: 0.10 \max \end{array}$ \\
\hline 321 & 531200 & 0.08 & 2.00 & 0.045 & 0.030 & 1.00 & $17,00-19.00$ & $9.00-12.00$ & $T 1: 5 \times C \mathrm{~min}$ \\
\hline 825 & N08825 & 0.05 & 1.0 & $\begin{array}{l}\text { not } \\
\text { snecified }\end{array}$ & 0.03 & 0.5 & $19.5-23.5$ & $38.0-46.0$ & $\begin{array}{l}\text { Mo: } 2.5-3.5 \\
T i: 0.6-1.2 \\
\text { Cu: } 1.5-3.0 \\
A 1: 0.2 \max \end{array}$ \\
\hline
\end{tabular}

(Information adapted f- ASTM specifications A-167, B-424, refer to ASTM Annual Book of 5tandards, ASTM, Philidelonia (1982)

Note: Other stainless alloys mentioned in text: $337 \mathrm{~L}$ is simllar to $316 \mathrm{~L}$ but with the Mo content increased to 3.00-4.00 and the $\mathrm{Cr}$ levels adjusted to $18.00-20.00$ and the $\mathrm{Ni}$ levels to $11.00-15.00$. 347 is a niobium stabilized stainless steel otherwise simflar to $32 l$. Nb content is specified as $10 \bar{x} C$ content.

* Unified Number System for Metals and Al loys. Society of Automotive Engineers, Inc. Publication SAE HSIU86a, Warrendale, PA (T977). 
TABLE 3 Actual Compositions of Alloys

it $\%$

\begin{tabular}{|c|c|c|c|c|c|c|c|c|c|c|c|}
\hline A7 loy & $C$ & $M n$ & $P$ & $S$ & Si & $\mathrm{Cr}$ & $\mathrm{Ni}$ & Mo & Cu & $n$ & Other \\
\hline 304L & 0.023 & 1.76 & 0.026 & 0.006 & 0.54 & 18.12 & 11.47 & 0.18 & 0.24 & 0.050 & bal-Fe \\
\hline 316L & 0.015 & 1.63 & 0.032 & 0.028 & 0.33 & 16.52 & 10.42 & 2.17 & 0.20 & 0.058 & bal-Fe \\
\hline $317 \mathrm{~L}$ & 0.019 & 1.83 & 0.033 & 0.026 & 0.54 & 18.37 & 13.64 & 3.18 & -- & 0.074 & bal-Fe \\
\hline 321 & 0.026 & 1.75 & 0.019 & 0.010 & 0.5 & 17.220 & 9.34 & 0.23 & 0.23 & 0.017 & $\begin{array}{l}\text { fi } 0.45 \\
\text { Co } 0.110 \\
\text { bal-Fe }\end{array}$ \\
\hline 347 & 0.063 & 1.49 & 0.022 & 0.004 & 0.51 & 17.19 & 9.30 & 0.290 & 0.180 & - & $\begin{array}{l}\text { Co } 0.030 \\
\text { Ta } 0.006 \\
\text { Nb } 0.794 \\
\text { ba }-F e\end{array}$ \\
\hline 825 & 0.035 & 0.79 & -- & 0.006 & $0.2 \bar{b}$ & 20.65 & 39.85 & 2.73 & 1.93 & -- & $\begin{aligned} \text { Fe } & 32.8 \\
\text { Ti } & 0.69\end{aligned}$ \\
\hline
\end{tabular}


JABLE 4 Corrosion Rates of Candidate Stainless Steels in $\mathrm{J}-13$ Water as Determined from Weight-Loss Data.

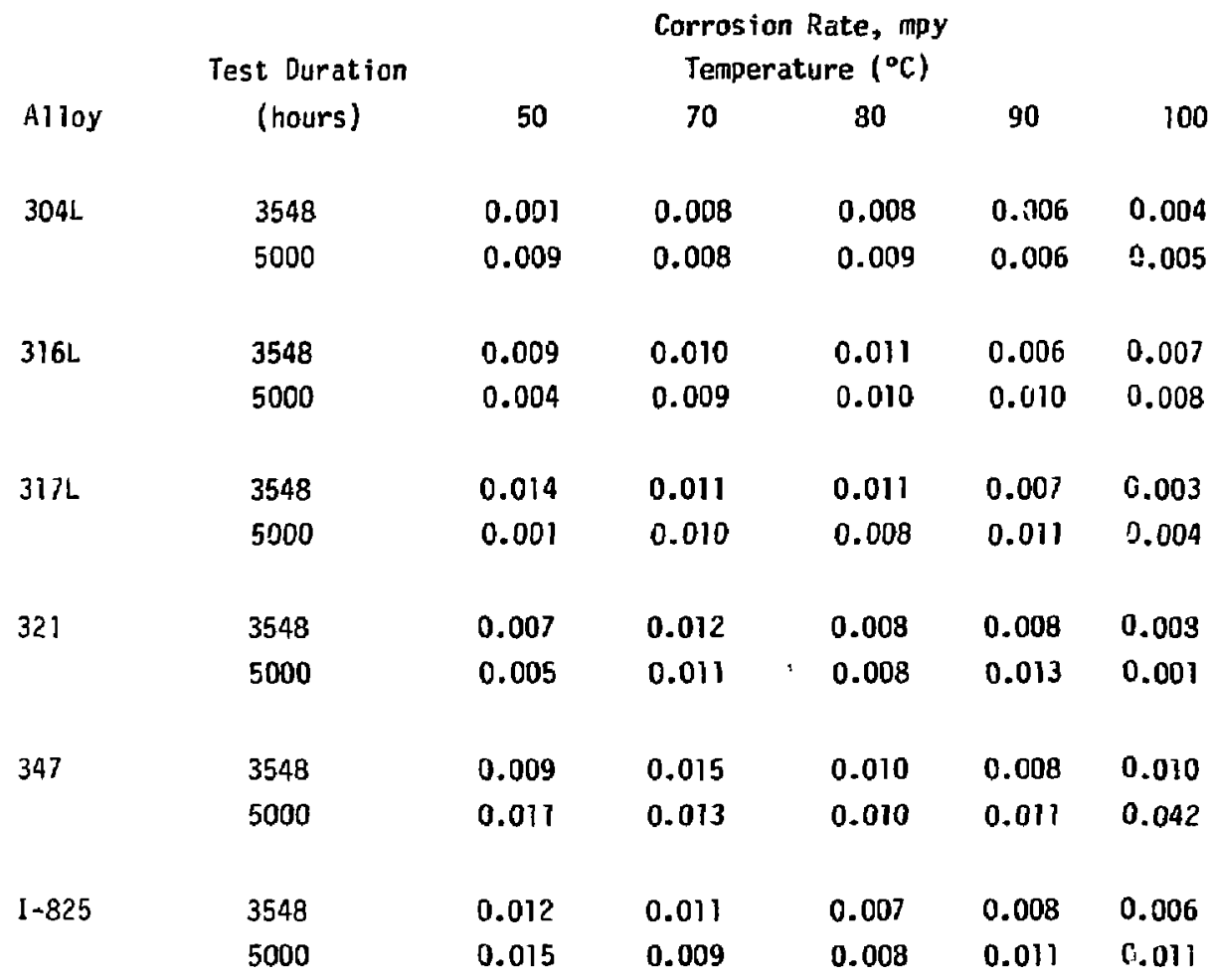

To express corrosion rates in $\mu \mathrm{m} / \mathrm{yr}$, use the conversion factor $0.001 \mathrm{mpy}=0.025 \mu \mathrm{m} / \mathrm{yr}$ 
Figure 1. Potentiodynanic anodic polarization curve for $304 \mathrm{~L}$ in J-13 well

water at $90^{\circ} \mathrm{C}$. Scan rate was $1 \mathrm{mV} / \mathrm{s}$. Scan starts from $\mathrm{E}_{\text {corr. }}$

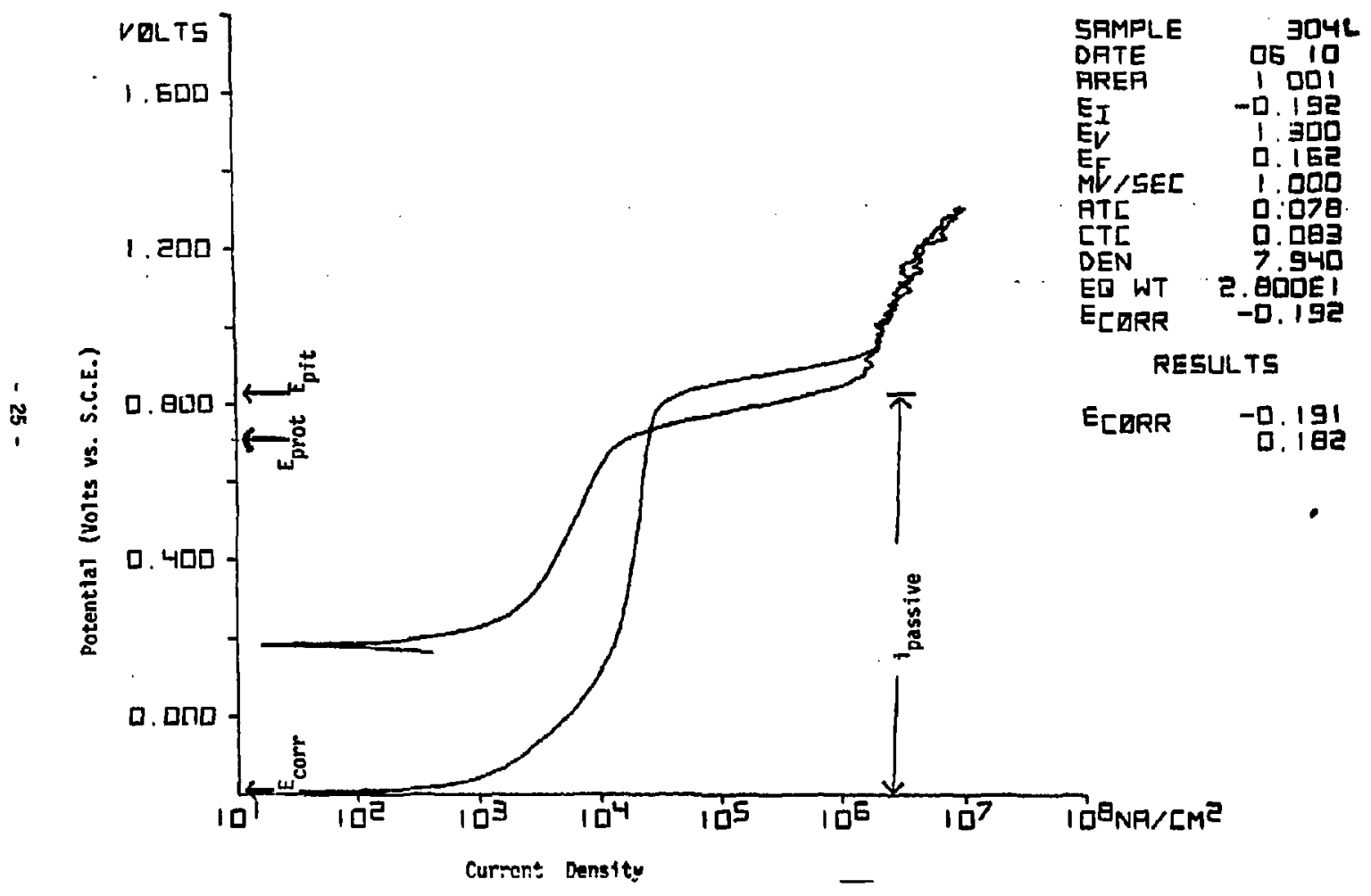


Figure 2. Electrochemical parameters for 304L in tuff-conditioned J-13 we 11 water a 5 function of temperature. All potentials are referenced to an S.C.E. at $25^{\circ} \mathrm{C}$.

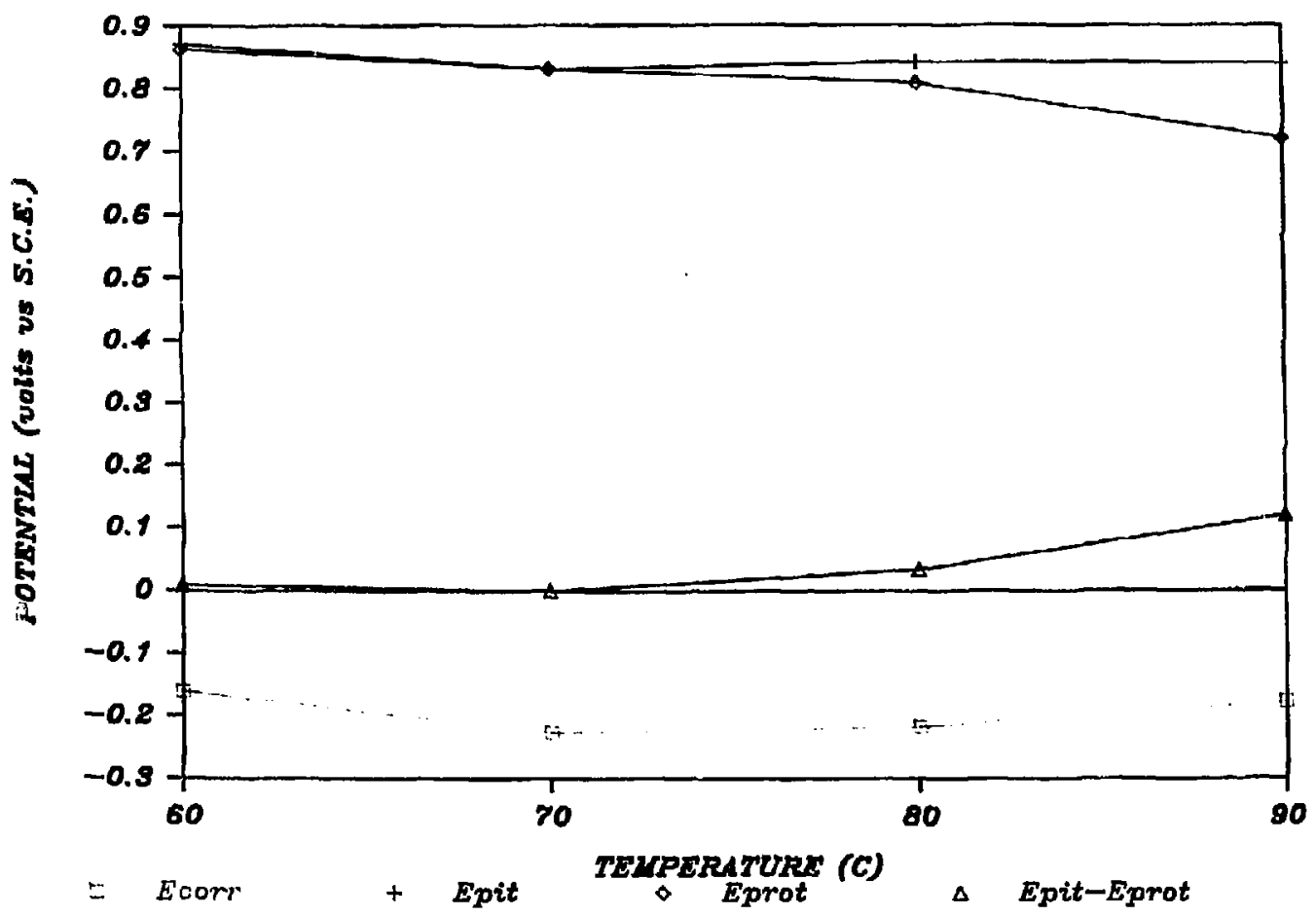



Figure 3. Electrochemical parameters for $316 \mathrm{~L}$ analogous to those of figure 2
for $304 \mathrm{~L}$.

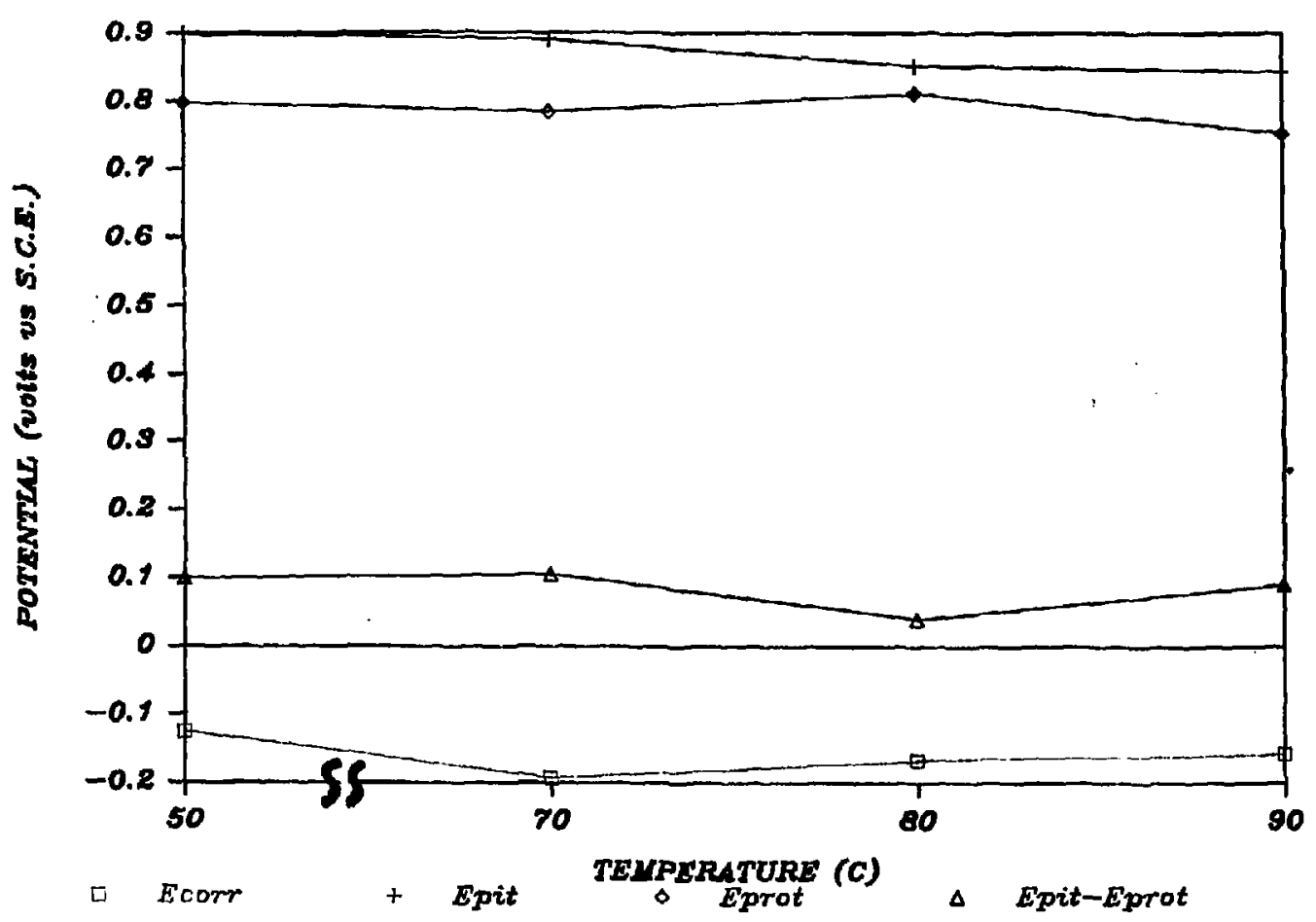


Figure 4. Electrochemical parameters for 1-825 analogous to those of figure 2 for $304 \mathrm{~L}$.

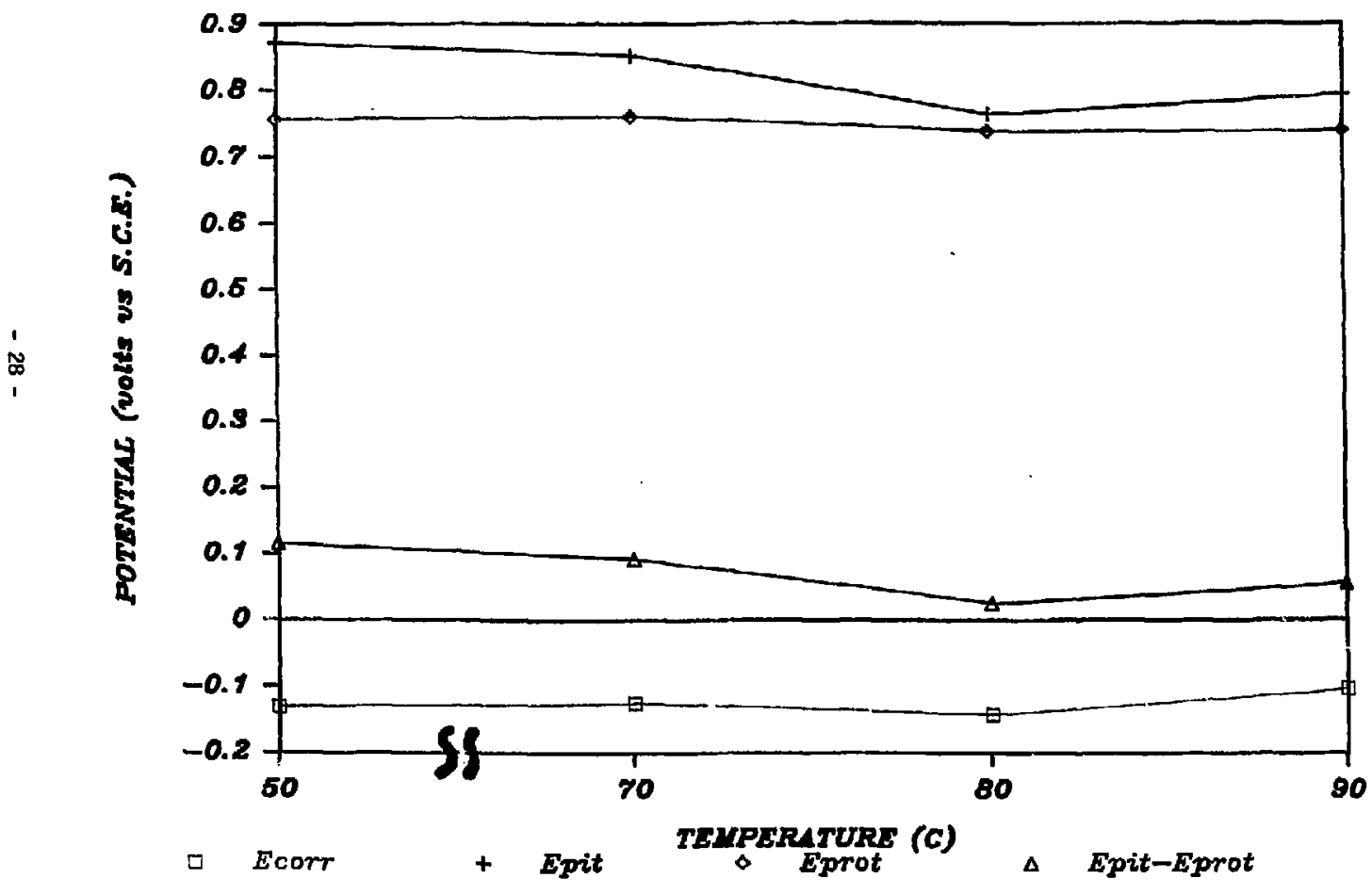

$\stackrel{1}{\infty}$ 
Figure 5. Potentiodynamic anodic polarization curve for $316 \mathrm{~L}$ in deaerated $\mathrm{J}-13$ well water with added $100 \mathrm{ppm} \mathrm{Cl}^{-}$at $90^{\circ} \mathrm{C}$. Scan rate was $1 \mathrm{mV} / \mathrm{s}$ and started from $E_{\text {corr. }}$.

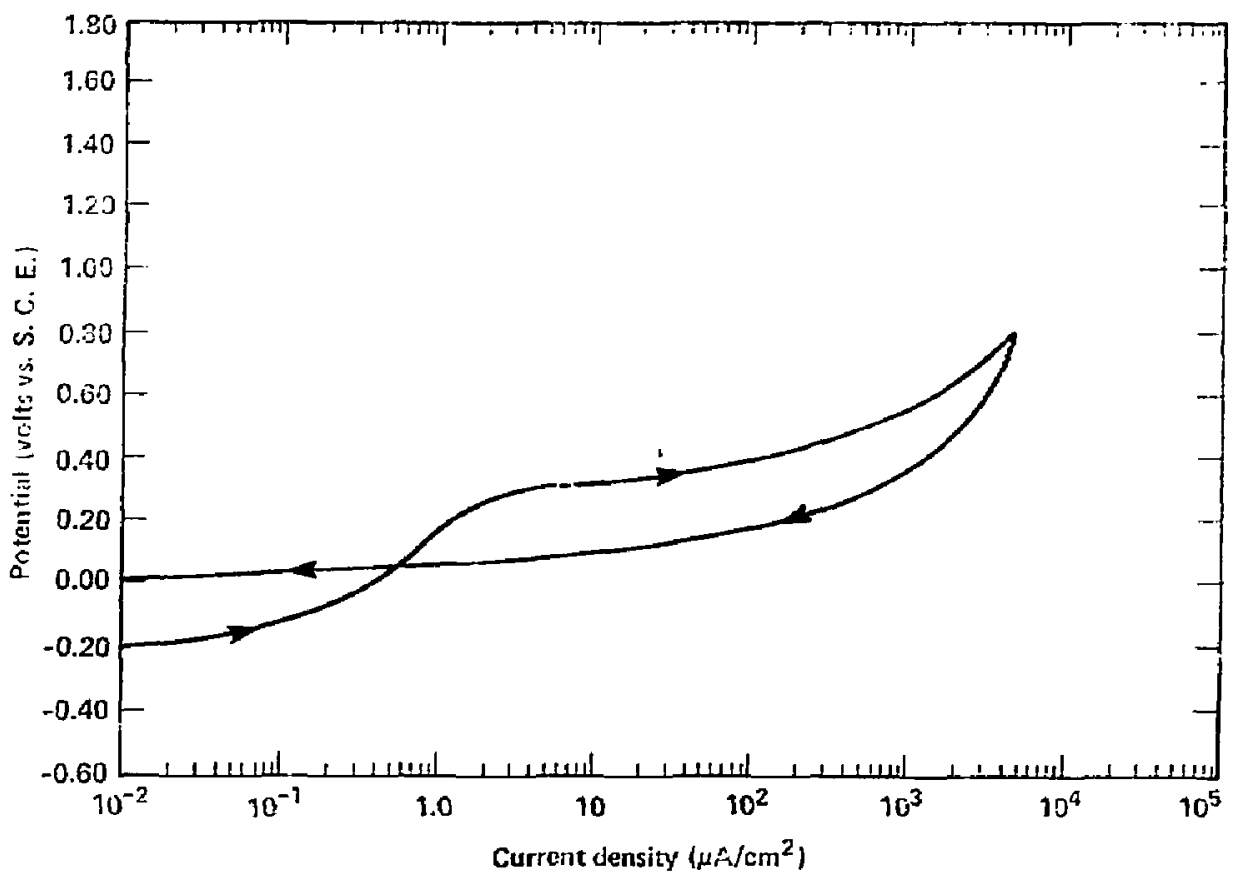




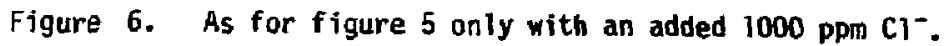

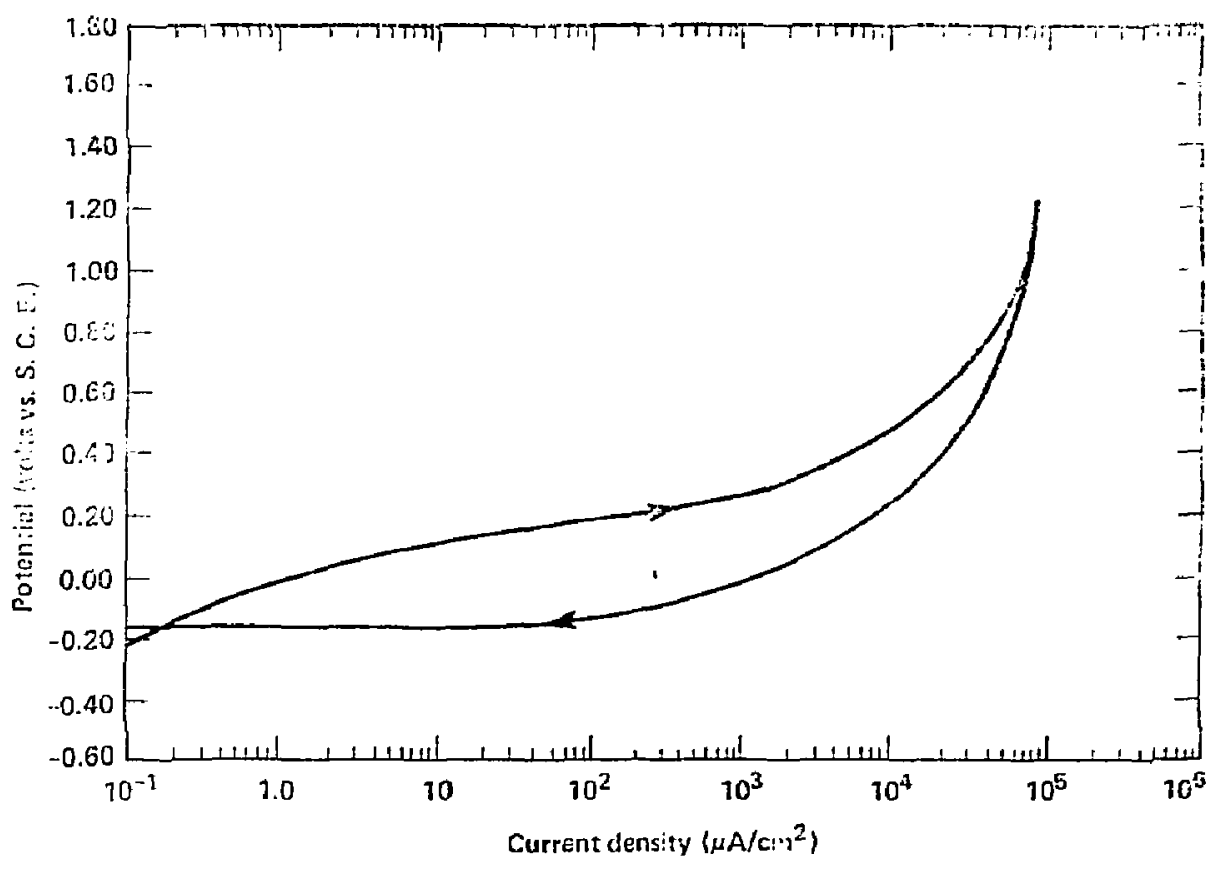


Figure 7. Values of $E_{\text {gocr }}$ and $E_{\text {pit }}$ for $304 \mathrm{~L}$ in tuff-conditioned $\mathrm{J}-13$ well water with gifferent Concentrations of $\mathrm{NaCl}$ at $90^{\circ} \mathrm{C}$.

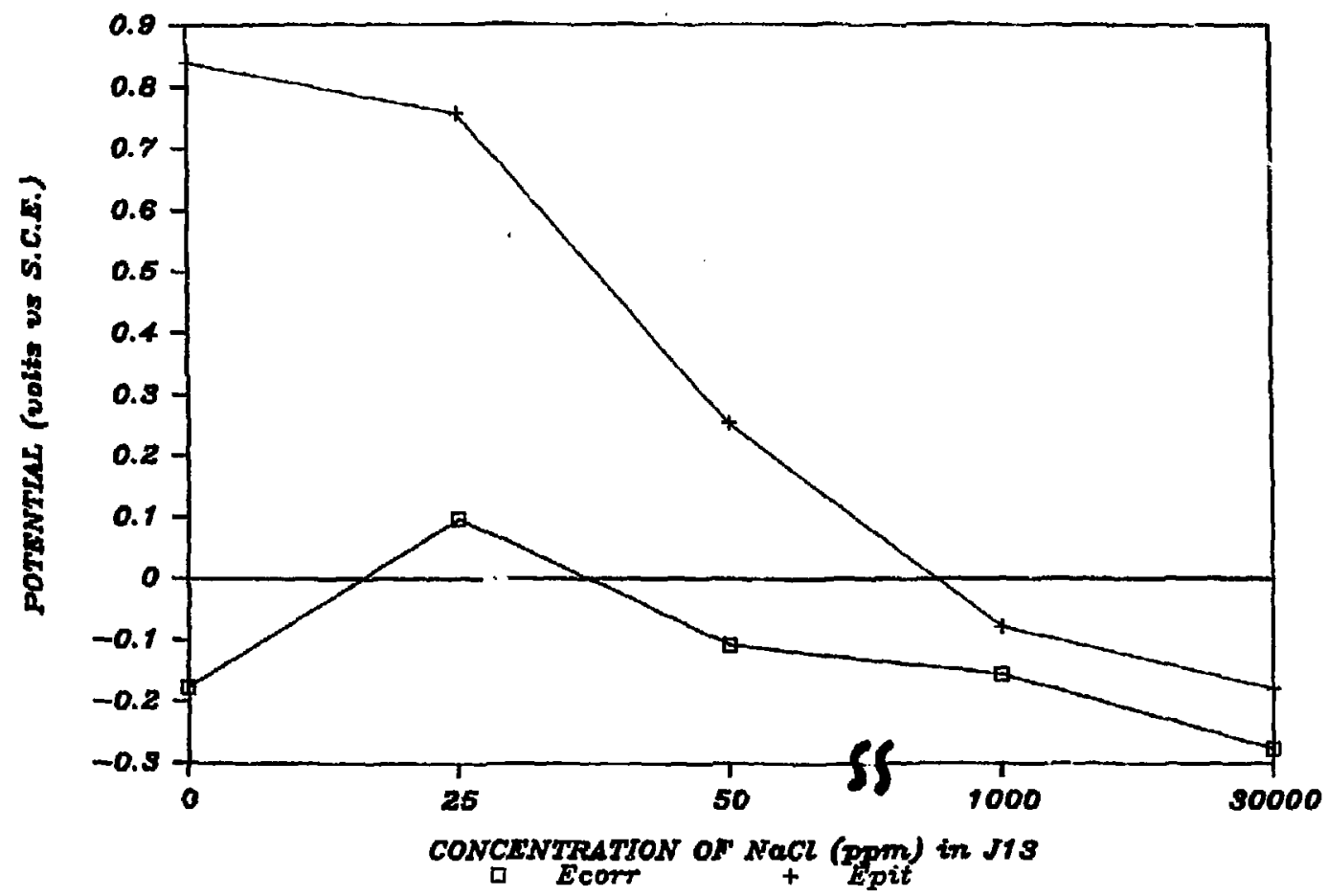


Figure 8. Values of $E_{\text {corr }}$ and $E_{p j t}$ as a function of temperature for $304 L$ in tuff-confitioned $\mathrm{J}-13$ well water to which $75 \mathrm{ppm} \mathrm{NaCl}$ has been added.

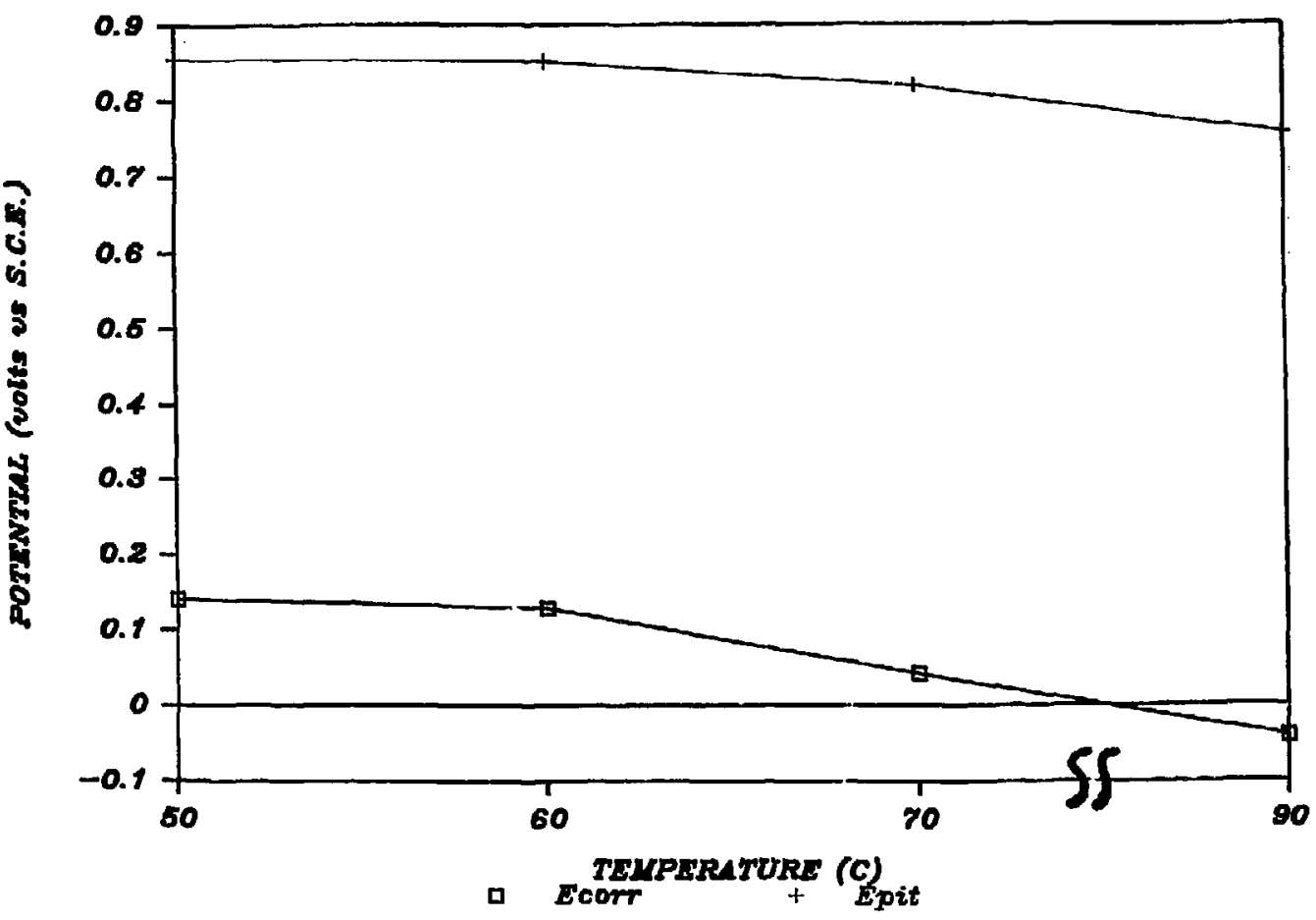


Figure 9. Electrochemical parameters for $304 \mathrm{~L}$ as a function of temperature in tuff-conditioned $\mathrm{J}-13$ well water to which $1000 \mathrm{ppm} \mathrm{NaCl}$ has been added.

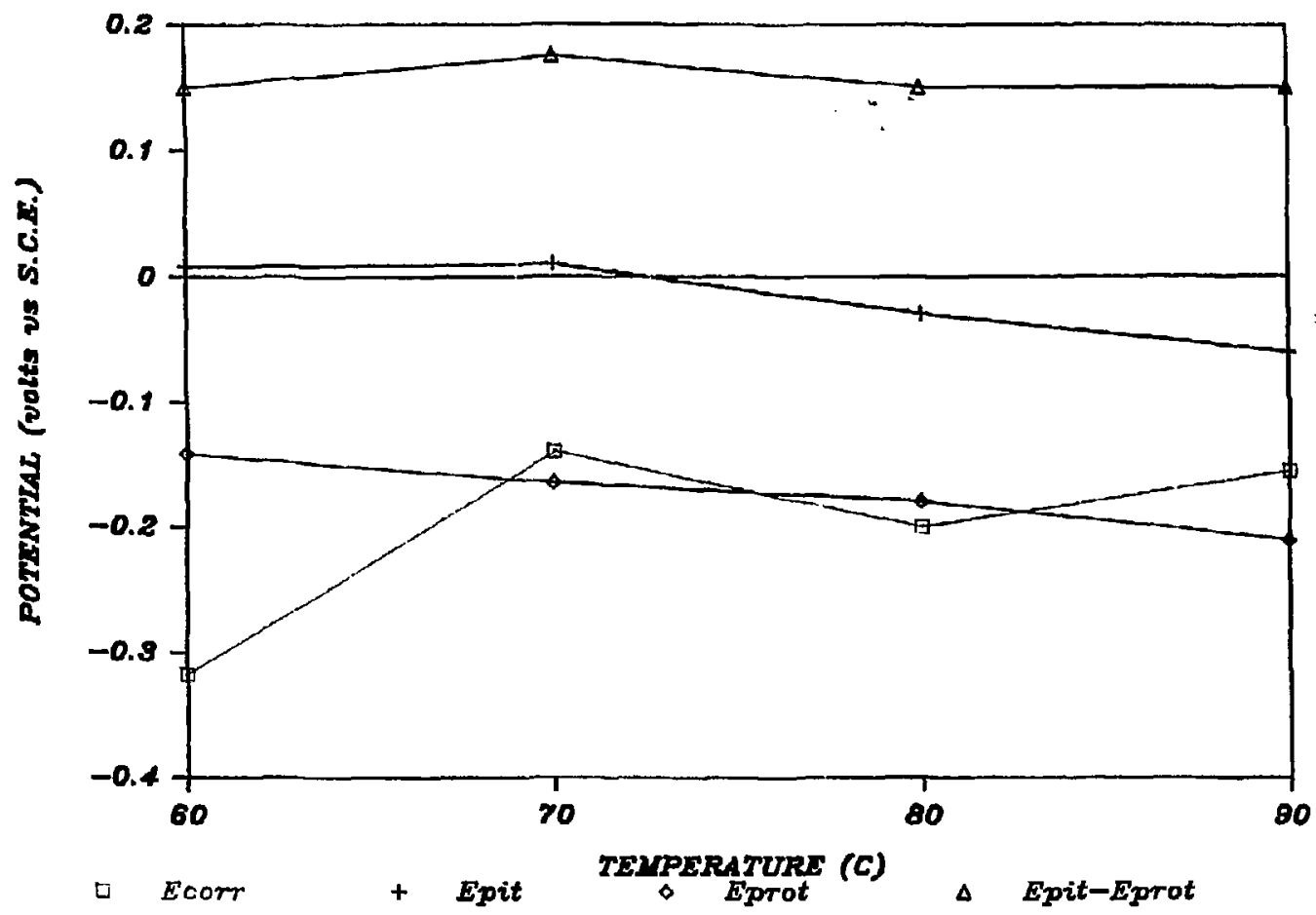


Figure 10. Example of the Tafel extrapolation methad used to calculate the electrochemical corrosion rate. Plot shown is for $316 \mathrm{~L}$ in tuff-conditioned $\mathrm{J}-13$ well water at $80^{\circ} \mathrm{C}$. The corrosion current is defined by the intersection of the linear anodic and cathodic Tafel 1 ines.
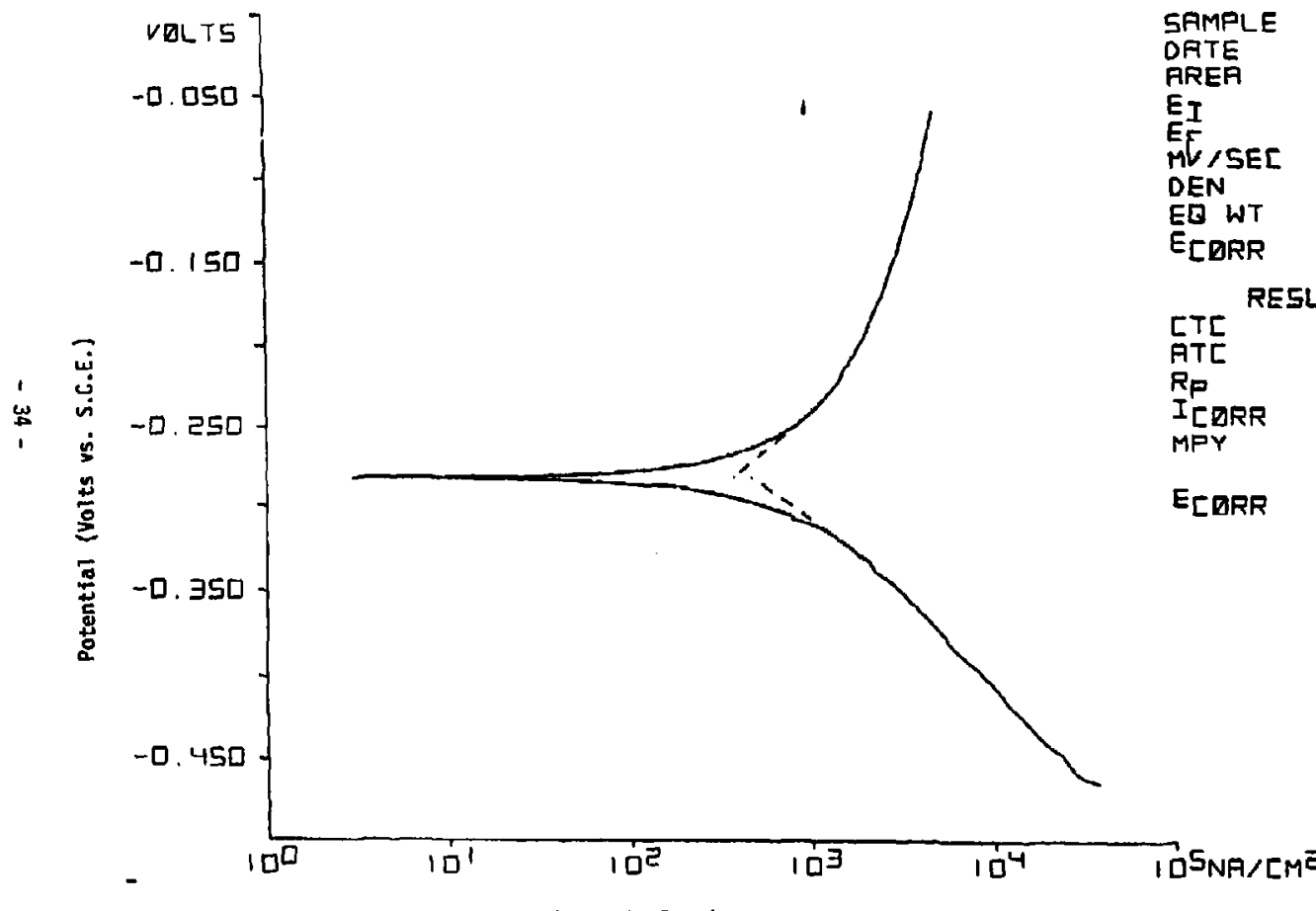

$\exists 16$ 06. 09 1. .01 -D. 드누 - D. DE4

1. . 000 7.980 -D. 254

\begin{tabular}{|c|c|}
\hline $\begin{array}{l}\text { LTE } \\
\text { ATE } \\
R_{P} \\
I_{\text {CDRR }}\end{array}$ & 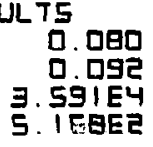 \\
\hline MPY & ๑. $2 \exists 6$ \\
\hline E[DRR & -0. 2曰3 \\
\hline
\end{tabular}


Figure 11. Example of the linear polarization resistance method used to obtain electrochemical corrosion rates. Conditions were the same as for figure 10. The linear segment of the curve generates a

"polarization resistance" from which a corrosion rate can be calculated. -
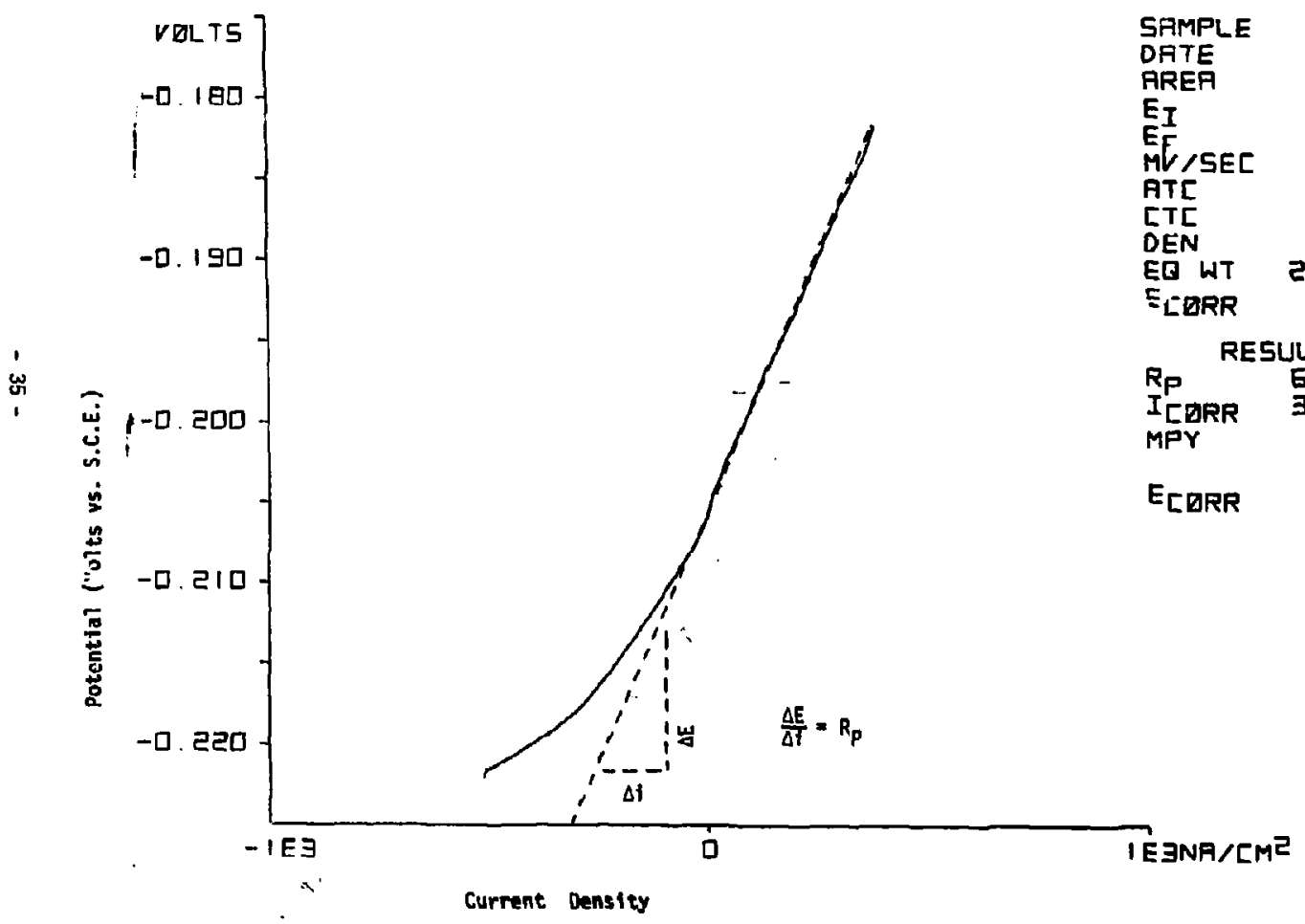
Figure 12. Plot of the electrochemical corrosion rates as determined both from Tafel extrapolation and linear polarization resistance for $304 \mathrm{~L}$ in tuff-conditioned $\mathrm{J}-13$ well water with an added $1000 \mathrm{ppm} \mathrm{NaCl.}$

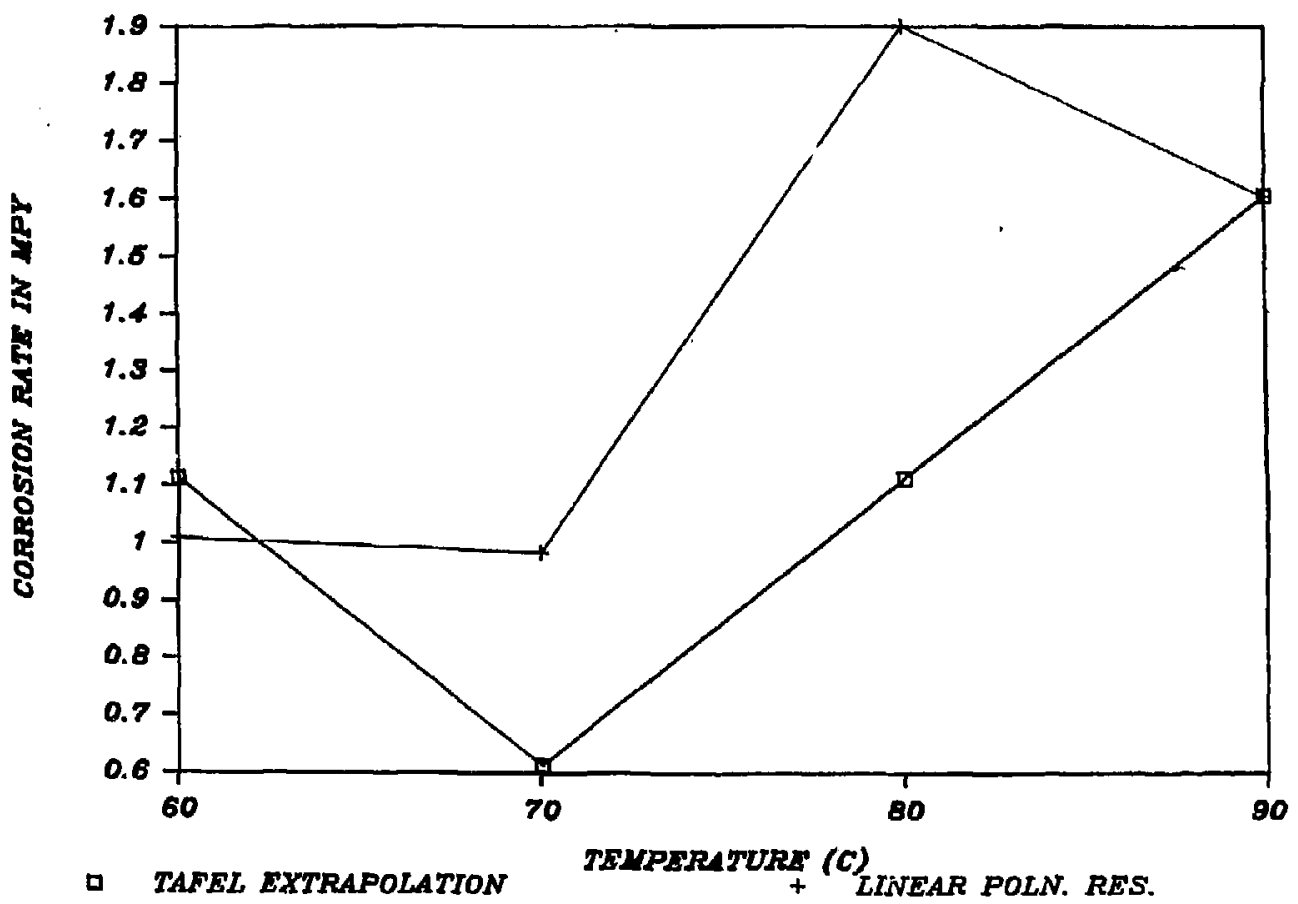


Figure 13. Electrochemical corrosion rates for $304 \mathrm{~L}$ in tuff-conditioned $\mathrm{J}-13$ well water at $90^{\circ} \mathrm{C}$ with different concentrations of added $\mathrm{MaCl}$.

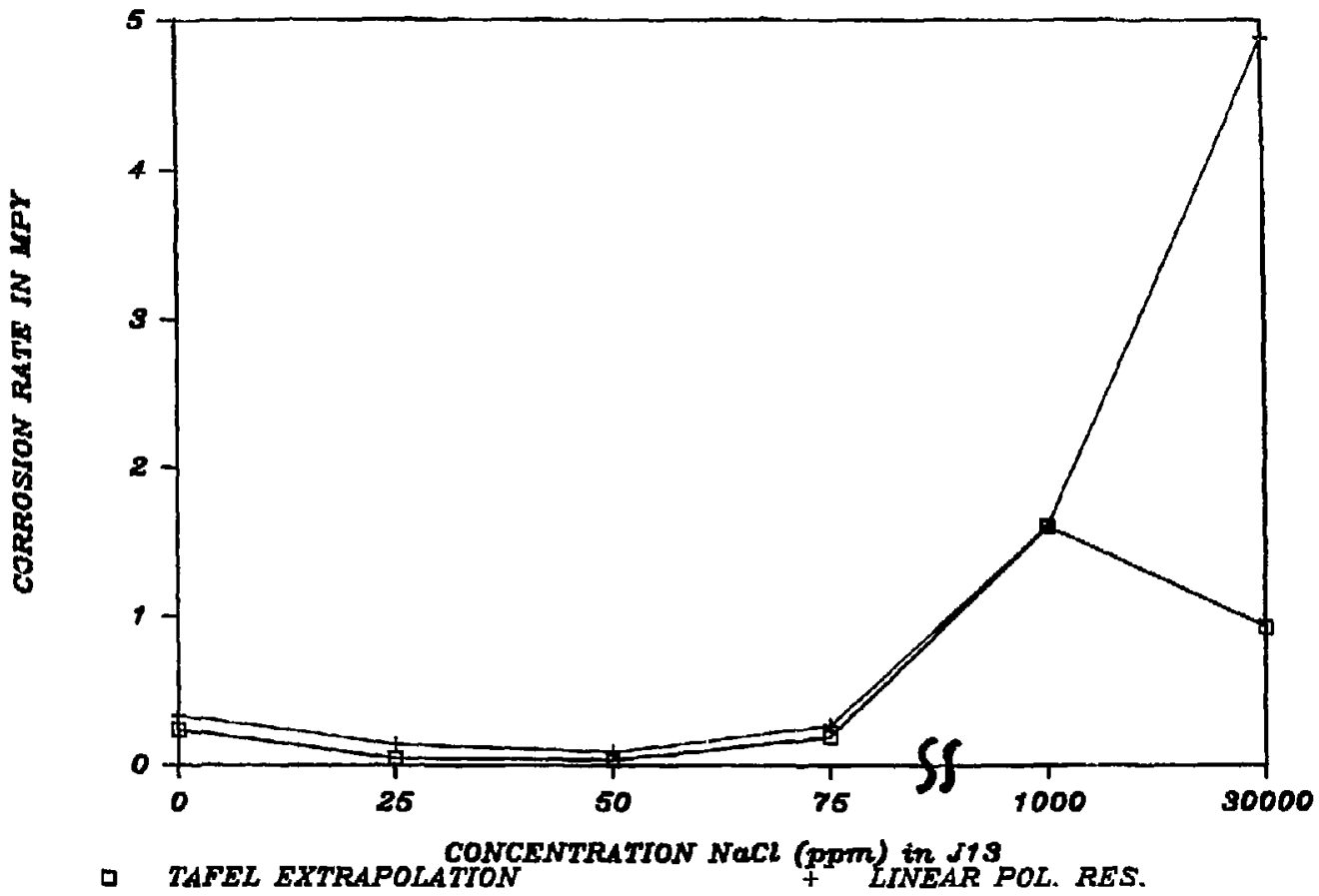


Figure 14. Corrosion rates for candidate alloys in tuff-conditioned $\mathrm{J}-13$ well water at different temperatures. The Tafel extrapolation method was used.

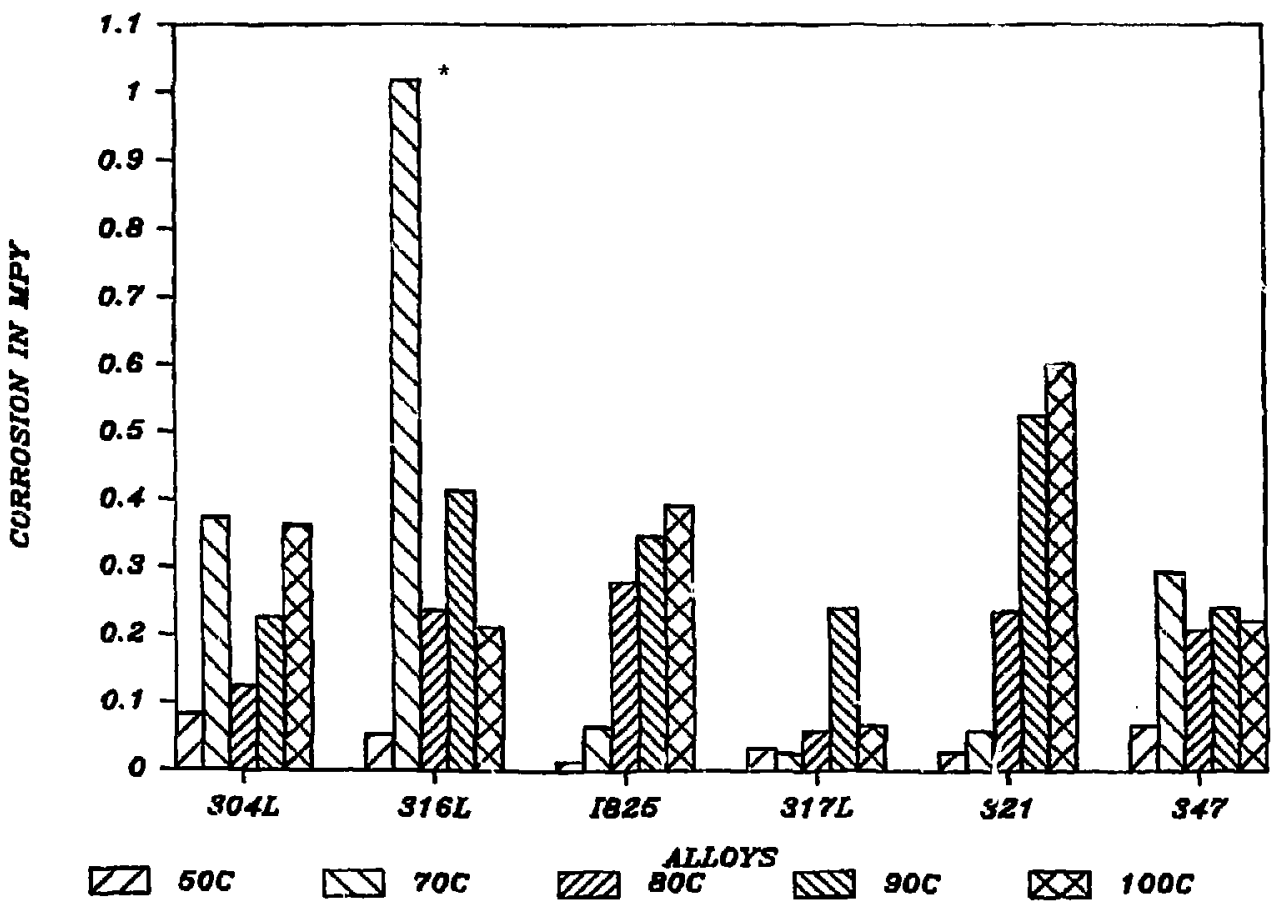

* In relation to the other values, this value appears anomalously high. See discussion on page 13. 
Figure 15. Electrochemical corrosion rates for candidate al loys in tuff-conditioned $\mathrm{J}-13$ at $90^{\circ} \mathrm{C}$ following different times of exposure. Tafel extrapolation was used.

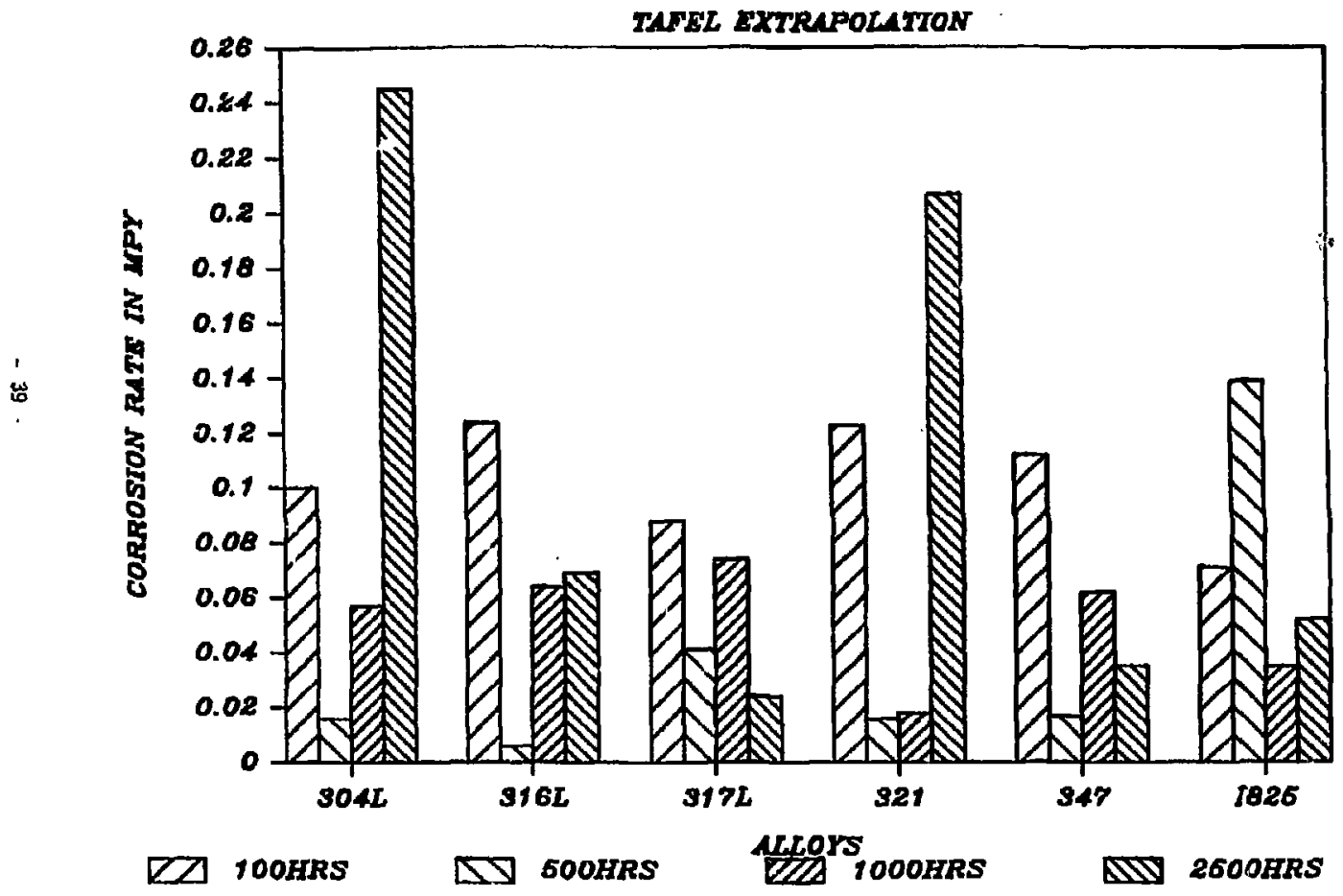

